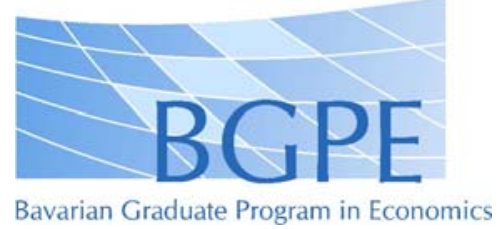

BGPE Discussion Paper

No. 133

\title{
The causal effect of family income on child health: A re-examination using an instrumental variables approach
}

\section{Daniel Kühnle}

\section{February 2013}

\section{ISSN 1863-5733}

Editor: Prof. Regina T. Riphahn, Ph.D.

Friedrich-Alexander-University Erlangen-Nuremberg

(c) Daniel Kühnle 


\title{
The causal effect of family income on child health: A re-examination using an instrumental variables approach* $^{*}$
}

\author{
Daniel Kuehnle ${ }^{a}$ \\ Department of Economics \\ Friedrich-Alexander-University Erlangen-Nuremberg
}

\begin{abstract}
Despite a recent growth in studies examining the association between family income and child health, very few studies investigate whether this is a causal relationship. This paper addresses this major methodological gap and examines the causal effect of family income on child health in the UK. Using rich observational data from a British cohort study, we exploit exogenous variation in local labour market characteristics to instrument for family income. We estimate the effect of family income on subjective child health and control for potential transmission channels through which income could affect child health. The results from our models provide novel evidence that income has a small but significant causal effect on subjective child health. Moreover, the analysis shows that parental health does not drive a spurious relationship between family income and child health as argued in recent contributions. We do not find significant effects of family income on chronic indicators of child health. The results are robust to different sets of instrumental variables, and to alternative measures of income.
\end{abstract}

JEL classification: I1.

Keywords: child health, income gradient, instrumental variables, transmission channels, UK.

${ }^{*}$ I am grateful for helpful comments received by David Johnston, Guyonne Kalb, Cain Polidano, Regina Riphahn, Stefanie Schurer, Tony Scott, and participants at the ESPE Conference 2012, the Brown Bag Series at the Melbourne Institute, and the doctoral workshop at the University of Erlangen-Nuremberg. Data from the Millennium Cohort Study (MCS) were supplied by the ESRC Data Archive. I would like to thank Stephen Jenkins, Lucinda Platt and Jon Johnson for their help in merging in external data.

${ }^{a}$ Correspondence to: Daniel Kuehnle. University of Erlangen-Nuremberg. Lange Gasse 20. 90403 Nuremberg. Germany. Email: daniel.kuehnle@wiso.uni-erlangen.de. Phone: +49 - (0)911 - 5302 - 230. Fax: +49 - (0)911 $5302-178$. 


\section{Introduction}

The literature on the relationship between family income and child health, the so-called 'income gradient', has grown substantially in the last ten years. Following the influential contribution by Case, Lubotsky, and Paxson (2002), a number of studies have examined the relationship between family income and child health for different countries. These studies universally find a positive association between parent-reported child health and family income in the US, the UK, Canada, Australia and Germany (Currie and Stabile, 2003; Currie, Shields, and Price, 2007; Propper, Rigg, and Burgess, 2007; Khanam, Nghiem, and Connelly, 2009; Reinhold and Jürges, 2012).

Examining the income gradient is important for a number of reasons. Several studies show that poor health in childhood correlates significantly with lower educational attainment, worse health and lower earnings in adulthood (see, for an overview, Currie, 2009). This finding fits the argument that 'health capital' affects the production of other forms of human capital, such as education or health itself, through 'self-productivity' and 'dynamic complementarity' (Heckman, 2007). Reducing inequalities in child health through early intervention policies may therefore help to improve the educational, health and labour market trajectories of children with poor health. Furthermore, policies that reduce the socio-economic gradient in child health may ultimately help mitigate the intergenerational transmission of poverty.

Despite the recent contributions to the literature, it remains unclear whether policies that change family income are an effective means of improving child health. So far the literature has been unable to establish whether income has a causal effect on child health, or whether the observed relationship between family income and child health is spuriously driven by unobserved factors. In fact, recent studies by Propper et al. (2007) and Khanam et al. (2009) find that the relationship between family income and child health becomes insignificant once the authors control for parental health. Provided that maternal health does not pick up unobserved maternal preferences that correlate with income, their findings suggest that public policy should address maternal health rather than family income to improve child health. 
The purpose of this paper is to address this gap by examining the causal effect of family income on subjective and objective measures of child health in the UK. The study contributes to the literature in several ways. Most importantly, given the lack of a natural experiment, we explicitly address the endogeneity of income with an instrumental variables (IV) approach. Income endogeneity is a large concern that could arise for three main reasons: as a result of unobserved heterogeneity, measurement error, or reverse causality. Most studies try to overcome the endogeneity problem by controlling for as many variables as possible to 'mop-up' (Gregg, Washbrook, Propper, and Burgess, 2005) any observed heterogeneity. However, this approach remains unsatisfactory as it does not address the issue of unobserved heterogeneity and ignores the twin problem of reverse causality and measurement error. In a novel contribution to this literature, we exploit exogenous variation in local labour market characteristics to instrument for family income.

Second, Currie (2009) points out the need for a closer examination of the transmission mechanisms that translate income into better health. Although Case et al. (2002) argue that 'either income is itself protective of children's health, or it is correlated with things that are protective of children's health. Perhaps both.', it seems doubtful that higher incomes per se affect the health status of children. Indeed, the observed relationship could be purely spurious as one can expect income to systematically correlate with unobserved factors that also affect the health of children. We exploit the rich data and control for several transmission mechanisms, such as nutrition, housing and parental health, that may account for the association between income and child health.

Third, the availability of panel data allows us to investigate more carefully the timing of family income. We are able to separate out the effect of current versus permanent income and are the first study to examine the effect once we instrument for income. Furthermore, we are able to examine the the effect of lagged income on current child health by instrumenting for these lagged variables.

Our results show that income has a statistically significant but very small causal effect on child health in the UK. We calculate that an increase in family income of about $274 \%$ is required to improve child health by one category. This is equivalent to moving from the 5 th to the 
99th percentile of the income distribution. The effects is stronger at the top end of the health distribution. Furthermore, we find small and mostly insignificant effects of family income on the indicators of chronic health conditions. Using the panel structure, we show that the timing of income does not matter for young children. In contrast to recent contributions by Propper et al. (2007) and Khanam et al. (2009), we provide robust evidence that parental health does not drive a spurious relationship between child health and family income. Although Currie et al. (2007) do not deal with the endogeneity of income, we confirm their finding that income is not a major determinant of child health in the UK. All results pass a wide range of robustness checks.

The paper is organised as follows. In section 2 we briefly review the relevant literature. Section 3 presents the conceptual framework for the production of child health and discusses the empirical identification strategy. In section 4 we describe the data and variables used in the analysis. Section 5 presents and discusses the main results. A variety of sensitivity tests validating the robustness of our results are presented in section 6 . We conclude the paper in section 7 .

\section{Previous literature}

The majority of the literature generated by economists examines the relationship between household income and parent-reported child health. Typically, subjective child health is measured on an ordinal scale (where 1=excellent, $5=$ poor) and an ordered probit model is used to estimate the relationship with the explanatory variables. In their seminal study, Case et al. (2002) examine the relationship between household income and subjective child health using a variety of US datasets for children aged 0-17. The study finds a significant positive association between household income and child health that is robust to different measures of child health and income. The results also reveal an increase in the gradient with the age of the child, implying that the effects of income are larger for older children.

The methodology of Case et al. (2002) was subsequently replicated and slightly modified by other studies in the US (Currie and Stabile, 2003; Chen et al., 2006), England (Currie et al., 2007; Propper et al., 2007), Australia (Khanam et al., 2009) and Germany (Reinhold and Jürges, 2012). These studies generally confirm the positive relationship between household income 
and subjective child health, controlling for a similar, or the same, set of explanatory variables. ${ }^{1}$ In particular, Currie and Stabile (2003) find a similarly sized income coefficient for Canada and thus provide evidence for a steepening income/health gradient in a country with universal health insurance. This suggests that universal access to health insurance does not reduce the income gradient or prevent the steepening of the gradient. In another US study, Chen et al. (2006) examine the association between income and various measures for child health, and explore whether this relationship changes with the age of the child. Although the authors use the same data as Case et al. (2002), the study finds no increase in the income/health gradient using subjective health. However, a follow-up study (Case, Paxson, and Vogl, 2007) shows that differences in the selection of the estimation sample can largely explain the differences between the two studies.

For the UK, Currie, Shields, and Price (2007) use English data for children aged 2-15 and confirm the existence of an income-gradient in England, although the size of the income coefficient is considerably smaller than in the US. The study shows that the association between income and child health disappears when using more objective measures of health such as professional examinations or blood test results. Furthermore, the authors show that nutritional intake and parental physical activity are influential transmission mechanisms in determining child health. The study does not find, however, that the gradient increases with the age of the child. In response, Case, Lee, and Paxson (2008) use the same data and exploit three additional years of data to show that the income gradient increases with age in the UK as well, although the income gradient remains smaller than in the US. In another study, Propper et al. (2007) use UK data for children aged 0-7 and find that although an income gradient exists, it does not increase with the age of the child and actually disappears when the authors control for the mother's selfrated health. The study also explores whether maternal behaviours in the production of child health are associated with income (such as nutrition, time spent with child, smoking), but find that these are largely insignificant. Khanam et al. (2009) use Australian data for children aged

\footnotetext{
${ }^{1}$ These include controls for parental education, age of the child, child cohort, family size, child's sex, child's ethnicity, presence of mother and father in the household, father's employment status. Notably, Propper et al. (2007) and Khanam et al. (2009) add additional control variables, including parental health, in contrast to the other studies.
} 
0-7 and also find that the relationship disappears once subjective maternal health is controlled for.

However, none of these studies explicitly deal with the endogeneity of income. The only study to our knowledge that uses an IV approach is Doyle, Harmon, and Walker (2007). However, the study uses 'grandparental smoking' as an instrumental variable. The instrument validity relies upon the very strong assumption that grandparental smoking does not correlate with any other unobserved determinants of child health. Case et al. (2002) and Currie et al. (2007) also instrument income using information about the job characteristics of workers in the household, but the results only appear in their footnotes. Indeed, the likely reason is that these instruments are invalid due to correlation with the unobservables.

\section{Analytical framework and empirical strategy}

In line with the previous literature we specify a production function of child health that depends on the quantity and quality of inputs. Specifically, we model child health in its reduced form as follows:

$$
\begin{aligned}
& H_{i t}=\alpha Y_{i t}+\epsilon_{i t} \\
& H_{i t}=\alpha Y_{i t}+X_{i t}^{\prime p} \beta_{p}+X_{i t}^{\prime c} \beta_{c}+\epsilon_{i t}
\end{aligned}
$$

where we first estimate the raw correlation between the health $(H)$ of child $i$ and family income $Y_{i t}$ at time $t$ as in equation (1). We then add some basic exogenous control variables for parental $\left(X_{i t}^{p}\right)$ and child $\left(X_{i t}^{c}\right)$ characteristics to arrive at our base case specification in equation (2). The base case uses a similar set of covariates as Currie et al. (2007) and includes controls for the child's age, sex and ethnicity, log of household size, the mother's and father's age, parental education, and dummies if either of the parents work. ${ }^{2} \beta_{p}$ and $\beta_{c}$ represent additional vectors of parameters to be estimated and $\epsilon_{i t}$ is a random error.

The main problem with identifying the effect of income on child health results from the potential endogeneity of income. Income might be endogenous for three reasons: first, in the

\footnotetext{
${ }^{2}$ For a detailed list and definition of variables used in the analysis, see Table A.1.
} 
presence of unobserved heterogeneity, the association between income and child health might be a purely spurious association as a third factor, such as parental health, or time preference rates (Fuchs, 1982), could correlate with both income and health. If this third factor positively correlates with both income and child health (such as parental health), the estimated income coefficient is biased upwards. The third factor could also be negatively associated with income and positively with child health (such as a preference to provide child care at home), imposing a negative bias. Secondly, reverse causality arises if mothers of children with poor health reduce their labour supply and have lower earnings as a consequence. This would impose an upward bias on the income coefficient. Third, income is likely to be measured with error which may bias the income coefficient towards zero due to attenuation bias. As a result of these opposing signs of bias, we cannot a priori assign a direction of the overall bias.

We employ an IV approach to deal with the endogeneity of income. The IV approach exploits variation in income generated by a factor that, holding other things constant, only affects children's health through parental income. To apply the two-stage least squares (2SLS) estimator, we need to specify the following first-stage equation for income:

$$
Y_{i t}=X_{i t}^{p \prime} \delta_{p}+X_{i t}^{c \prime} \delta_{c}+Z_{i t} \delta_{z}+\mu_{i t}
$$

A valid instrument $Z_{i t}$ needs to correlate with income, i.e. $\delta_{z} \neq 0$, and must be uncorrelated with the error term from equation (2), i.e. $\operatorname{cov}\left(Z_{i t}, \epsilon_{i t}\right)=0$. We employ two completely different instruments that satisfy these conditions and that have been used in slightly different contexts in the literature before - local labour market characteristics, and the occupational status of the grandparents (see Maurin, 2002; Xu and Kaestner, 2010). ${ }^{3}$

For our main results, we instrument family income using local labour market characteristics that we capture with local unemployment rates. Given that we expect a strong correlation between unemployment rates and family incomes, these are particularly suitable instruments in the first stage. The identification strategy assumes that these local characteristics do not have a direct impact on child health other than through family income. We now discuss factors that may

\footnotetext{
${ }^{3}$ We use the occupational status of the grandparents as a robustness check. The justification for the instrument and the estimation results are presented in section 6.1.
} 
invalidate this assumption. The unemployment rate should not directly influence child health as young children do not participate in the labour force in the UK. Since unemployment rates may have second order effects on child health via parents' mental health (Paul and Moser, 2009), we include controls for parents' physical and mental health in our estimations. Unemployment rates might also affect child health through the quality or availability of hospitals. We believe this not to be a problem in the UK as hospital funding does not depend on regional incomes but instead on the centralised National Health Service. Furthermore, we include regional dummies in our estimations. Recent publications have highlighted the importance of neighbourhoods as a determinant of health (Bilger and Carrieri, 2013; Jacob, Ludwig, and Miller, 2013). These studies show that social, physical and environmental factors have a causal effect on adult health and child mortality. Unfortunately, the MCS does not provide information on the neighbourhoods of families. However, we can control for council housing as a proxy for poor neighbourhood quality as council housing estates are typically areas of high deprivation (Atkinson and Kintrea, 2001). ${ }^{4}$ To the extent that we're not capturing neighbourhoods adequately, our estimated income coefficients may be biased upwards. Finally, location may not exogenous as families may decide to move to regions that suit the parents' preferences for work (i.e. based on low/high unemployment rates). However, the opportunity costs of moving are generally higher for families with school-aged children compared to families without children or with children who have already left school (Long, 1972; Mincer, 1977). We confirm low mobility patterns empirically in our data, i.e. that families with school-aged children are less likely to move. ${ }^{5}$ Based on these considerations, we argue that local unemployment rates can reasonably be assumed to be exogenous to the child health equation.

In our empirical approach, we first estimate equations (1) to (2) using both OLS and 2SLS to compare the coefficients. However, the interpretation of the coefficients differs between the OLS and 2SLS estimators. Whilst OLS produces average marginal effects, 2SLS produces local average treatment effects (LATE, see Imbens and Angrist (1994)). The LATE identifies the

\footnotetext{
${ }^{4}$ In the UK, social or public housing is known as 'council housing'.

${ }^{5}$ In our study, about $16.2 \%$ and $9.8 \%$ of families moved at waves 3 and 4 , respectively. Of those who moved, the vast majority $(89.5 \%)$ stayed within the same region. We thus confirm the low mobility of families with children for our data.
} 
effect of variation in income caused by changes in local employment conditions for the group of compliers. The LATE for the group of compliers generated by variation in local unemployment rates may, for instance, be interpreted as the effect of the business cycle (Xu and Kaestner, 2010).

In the second part of the analysis, we examine the transmission mechanisms through which family income could influence child health. We derive and classify potential mechanisms from the literature on the determinants of child health in section 4.4. For the analysis, we need to add each group of mechanisms separately to our base case specification. This allows us to disentangle how much of the income effect is mediated by each group:

$$
\begin{aligned}
& H_{i t}=\alpha Y_{i t}+X_{i t}^{p \prime} \beta_{p}+X_{i t}^{c \prime} \beta_{c}+T M_{i j t}^{\prime} \gamma_{j}+\epsilon_{i t} \\
& H_{i t}=\alpha Y_{i t}+X_{i t}^{p \prime} \beta_{p}+X_{i t}^{c \prime} \beta_{c}+\sum_{j=1}^{J} T M_{j}^{\prime} \gamma_{j}+\epsilon_{i t}
\end{aligned}
$$

We denote each group $j$ of transmission mechanisms by a vector $T M_{i j t}^{\prime}$ and add it separately to the base case specification as in equation (4). In the final regression, equation (5), we control for all transmission mechanisms simultaneously.

However, the interpretation of changes in the income coefficient with the inclusion of the transmission mechanisms differs between the OLS and the 2SLS estimates. Using 2SLS we condition on the transmission mechanisms in the first stage and thus purge instrumented income of the effect of these mechanisms. This means that the OLS estimates can be interpreted as transmission mechanisms, whereas the instrumented results provide estimates of the causal effect of income conditional on a particular set of transmission mechanisms. The approach implies that the instruments are independent of the additional covariates if the 2SLS estimates remain stable with the inclusion of the transmission mechanisms (Angrist and Pischke, 2009).

\section{Data and variable definitions}

We use British data from the Millennium Cohort Study (MCS), a longitudinal cohort study representative of all children born in the UK between 2000 and 2001. The MCS provides a rich collection of information on the child's development, the socio-economic context and 
the family's circumstances. The survey is a disproportionately stratified clustered sample and provides detailed information capturing the emotional, physical, cognitive, and health-related development of the child. Parents were first asked to subjectively assess their child's health in wave 3 of the MCS. We therefore use data from waves 3 and 4 (collected mainly in 2006 and 2008) when the children were aged 4-6 and 6-8, respectively, and supplement these with information merged in from earlier waves. Our final estimation sample includes 11,590 children from wave 3 and 10,552 children from wave 4.

\subsection{Measuring income}

We construct several measures of household income that are consistent with definitions used by Case et al. (2002) and Currie et al. (2007). We derive these measures from the questionnaire which asks the respondent to which of 19 income bands the household belongs. The MCS defines net household income as the combined annual income from all sources after deductions (tax, national insurance, etc.). We first convert the banded income variable into a pseudocontinuous measure by assigning the mid-point of each income interval to the respondent. We then convert all prices to 2005 prices using the monthly consumer price index and take the natural logarithm to capture potential income non-linearities. Average annual net family income in 2006 and 2008 is $£ 29,154$ and $£ 31,610$, respectively. ${ }^{6}$ Consistent with the literature, we also generate a measure of permanent household income calculated as the mean of current income across all available waves. As a robustness check, to reflect household composition, we apply the equivalence scales suggested by Gravelle and Sutton (2003) to generate measures of permanent and current equivalised income. ${ }^{7}$

\subsection{Child health}

We follow the literature and use parent-reported child health as the main dependent variable. In the MCS, the primary carer rates the child's health according to the following ordinal scale:

\footnotetext{
${ }^{6} \mathrm{We}$ applied sampling weights to these figures to account for the sampling design.

${ }^{7}$ Gravelle and Sutton (2003) define equivalised incomes as follows:

equivalised income $=\frac{\text { household income }}{\sqrt{\left(\text { adults }+0.5^{*} \text { children }\right)}}$.
} 
$1=$ poor, $2=$ =fair, $3=$ good, $4=$ very good, $5=$ excellent. $^{8}$ Child health is distributed as shown in Figure 1 with a mean of 4.3 and standard deviation of 0.85 in wave 3 ( 4.5 and 0.77 in wave 4, respectively). The graph shows that the majority of children are in excellent or very good health. However, health clearly differs by income groups as shown in Figure 2. The figure shows that children from poorer families are consistently in worse health than richer children. In addition to subjective child health, the MCS provides information on specific conditions which are classified using the International Classification of Diseases (ICD-10). We generate binary indicators for whether the child currently has a chronic illness, and whether this illness is limiting to the child. ${ }^{9}$

\section{[Insert Figures 1 and 2 here]}

\subsection{Base case specification}

The base case specification contains a basic set of controls for family and child characteristics. In terms of family characteristics, we control for the household size (log) and whether the natural father is resident in the household. We include dummies for the child's sex, ethnic background, age, and height. Controls for the mother's characteristics include age, height and education. For education, we construct four dummy variables for the highest level of educational attainment. We also control for a set of regional indicators.

\subsection{Transmission mechanisms}

\subsubsection{Parental health}

Clearly, parental health is an important direct and indirect determinant of child health (Kelly and Bartley, 2010). We include dummy variables for whether either parent currently has a longstanding illness, and whether this long-standing illness is limiting. To capture mental health, we control for whether either parent has ever been diagnosed with depression or serious anxiety by a doctor. We also control for the parents' body-mass index (BMI).

\footnotetext{
${ }^{8} \mathrm{We}$ reversed the coding of the variable to facilitate the interpretation of coefficients.

${ }^{9}$ Due to small cell sizes, we are unable to perform the analysis for more specific indicators of health (see Table A.4).
} 


\subsubsection{Housing}

Housing conditions may also have a direct effect on child health. Several studies show that children living in damp houses have an increased risk of suffering from respiratory illnesses (Peat, Dickerson, and Li, 2007; Andriessen, Brunekreef, Roemer, et al., 1998). We therefore generate a dummy variable whether the house suffers from dampness. To serve as a proxy for quality of the house and the local neighbourhood, we additionally control for whether the family lives in a council house.

\subsubsection{Foetal-origins hypothesis}

We also construct variables to address the implications of the foetal-origins hypothesis. This hypothesis argues that maternal behaviour (such as drinking and smoking) and nutritional intake during pregnancy not only have immediate effects in-utero, but have long-lasting health consequences (Barker, 1998; Ravelli, van der Meulen, Michels, Osmond, Barker, Hales, Bleker, et al., 1998). Economic studies provide strong empirical support for this hypothesis (Almond and Currie, 2011). To address these concerns, we control for the child's birth-weight and the number of problems that occurred during the birth of the child. We also include a dummy for whether the child was breastfed as mothers who breastfeed may be different in their unobservable characteristics from mothers who do not breastfeed.

\subsubsection{Nutrition}

As Currie et al. (2007) show, nutrition is an influential transmission mechanism. If richer families purchase and provide higher quality foods, failure to account for nutrition will bias the income gradient upwards. The questionnaire provides information about the amount of fruit consumed daily by the child (ranging from 0 to three or more portions) and whether the child snacks on different types of foods between meals. Factor analysis of these 13 categories reveals that these variables load onto two factors that we interpret as savoury and sweet foods. We therefore generate two factors scores that capture the child's consumption of savoury or sweet foods between meals. Furthermore, we control for whether the parents pay for school meals to 
proxy the quality of meals provided at school.

\subsubsection{Parental smoking}

A substantial body of evidence exists demonstrating the negative effects of parental smoking, both pre- and post-natal, on child health (Cook and Strachan, 1999; Gilliland, Li, and Peters, 2001). We therefore separately control for the number of cigarettes smoked by the mother and partner, and whether anyone smokes when the child is present in the same room.

\subsubsection{Behavioural problems}

Finally, we extend the literature by including proxy-variables that capture a child's behavioural difficulties. If, for instance, parents of children with behavioural problems are more likely to have lower earnings and if children with behavioural difficulties are more likely to be in poorer health, the income coefficient will be biased upwards. Indeed, a recent study demonstrates a significant link between the psychosomatic problems and bullying at school (Gini and Pozzoli, 2009). We therefore include dummy variables if the child is being bullied at school; if the child bullies other children at school; and whether the child has irregular bedtimes.

\subsection{Instruments}

We merge in external information for the local labour market characteristics, which are available at the level of local authorities, from the British Office for National Statistics (ONS). ${ }^{10,11}$ Figure A.1 provides a map showing the boundaries of all 406 local authorities. ${ }^{12}$ For the analysis we use the following three instruments: the local unemployment rate; information on the number of business start-ups and closures; and the average regional household income. For the main analysis, we employ the unemployment rate as the main instrumental variable. Based on the business registrations data, we generate a business growth variable. ${ }^{13}$ To examine the robustness

\footnotetext{
${ }^{10}$ We downloaded the data from the official website: http://www.nomisweb.co.uk. Last accessed July 2012.

${ }^{11}$ The ONS defines local authorities as '[...] the lower tier of local government [...] including non-metropolitan districts, metropolitan districts, unitary authorities and London boroughs in England; unitary authorities in Wales; council areas in Scotland'.

${ }^{12}$ See following website for a map: http://www.ons.gov.uk/ons/guide-method/geography/beginner-sguide/maps/all-local-authorities-in-the-uk-effective-at-31st-december- -2011.pdf. Last accessed February 2013.

${ }^{13}$ Since the ONS collected the business registrations data only until 2007, we are required to use the 2007 values for the interviews conducted in 2008.
} 
of the results to the choice of instruments, we use different combinations of these three variables as instrumental variables in section 6.1.

As a further robustness check, we construct an alternative set of instruments based on the grandmother's and grandfather's occupational status (see Maurin, 2002, for another application). Again, the identification strategy rests on the assumption that the occupational status of the grandparents is correlated with family income, but not correlated with any other unobserved factors that affect child health. The occupation status is coded according to the British Standard Occupational Classification (2000) which classifies occupations into nine major groups. ${ }^{14}$ Due to small frequencies, we join the three smallest groups, which are also similar in the required skill level. ${ }^{15}$ Finally, we combine the information on up to four grandparents by counting how many grandparents are in each category. We thus arrive at a set of seven instrumental variables that range from 0 to 4 .

In Table A.2 we provide full summary statistics for variables used in the analysis.

\section{Empirical analyses}

\subsection{Does income have a causal effect?}

Table 1 summarises the estimated income coefficients from models with different control variables for the pooled sample of children, as well as separately by age of the child. First we focus on Panel A and discuss the pooled sample not accounting for the endogeneity of income in column 1. Once we control for the base case variables, the estimated coefficient shows that a $100 \%$ increase in income is associated with an increase in child health of about 0.150 points. This is a rather small association given that child health has a mean of 4.3 and standard deviation of about 0.8 .

\section{[Insert Table 1 here]}

\footnotetext{
${ }^{14}$ These groups are: managers and senior officials; professional occupations; associate professional and technical occupations; administrative and secretarial occupations; skilled trades occupations; personal service occupations; sales and customer service occupations; process, plant and machine operatives; and elementary occupations.

${ }^{15}$ These are: administrative and secretarial occupations; personal service occupations; sales and customer service occupations.
} 
Column 2 presents the results when we instrument for income using the local unemployment rate. The results from Panel A show that income has a significant causal effect that is considerably larger than the OLS estimate. The diagnostic tests for the base case specification confirm the validity of the instruments. The instrumental variables strongly correlate with family income $(\mathrm{F}=158.6)$ and the model passes the underidentification test $(\mathrm{p}=0.000) .{ }^{16}$ As found in other studies that instrument household income (Doyle et al., 2007; Maurin, 2002), the effect of income is greater for the IV estimates although less precise. Given the strength of the instrument and the large absolute differences between the OLS and IV estimates, the comparison implies that previous studies using OLS and banded income variables are likely to suffer from relatively large endogeneity biases. ${ }^{17}$

In terms of size, column 2 indicates that a $100 \%$ increase in income improves child health by about 0.364 points given the base case specification. Put differently, it requires an increase in family income of about $274.7 \%$ to move a child into a higher health category. This is equivalent to an increase in log income by about 4 standard deviations which is equivalent to a move from the 5th to the 99th percentile of the income distribution.

The results from estimating separate models by age of the child are presented in columns 3-6. For the two age groups, our results confirm the findings by Currie et al. (2007) who find no evidence of an age gradient in income for the UK. These results are confirmed if we account for the endogeneity of income.

\subsection{Transmission mechanisms}

Panel B in Table 1 presents the results once we control separately, and jointly, for the impact of each set of transmission mechanisms in addition to the base case variables. The regressors included in each additional group are listed in Table A.1. All instrumented models pass the first-stage F-test and the underidentification test (see Table A.5 for details).

\footnotetext{
${ }^{16}$ Table A.5 provides results from diagnostic tests such as the first-stage F statistics and the p-value from an underidentification test. Under the null hypothesis of the underidentification test, the model is underidentified. A rejection of the Null thus implies that the instrumental variable is relevant and correlated with the endogenous variable.

${ }^{17} \mathrm{We}$ also explored the robustness of the results with respect to unobserved heterogeneity by estimating a variety of random-effects models. Both the GLS and IV (using the same instrument as in Table 1) random-effects models, that we specified with and without group means of time-varying covariates (Mundlak, 1978), produced almost identical results and are available upon request.
} 
We first discuss the results in the first column for the pooled sample, not accounting for the endogeneity of income. Including controls for parental health, the OLS estimate remains highly significant and reduces from 0.150 to 0.129 . This finding stands in stark contrast to results by Propper et al. (2007) and Khanam et al. (2009) who find no significant association between income and child health controlling for maternal health. Our OLS results do not confirm the argument that the relationship between child health and family income might be spuriously driven by parental health. The differences between our and their studies might arise due to using different proxy variables for parental and child health. For example, Propper et al. (2007) do not use the same dependent variable but instead whether the child belongs to the top quintile by number of symptoms or poor health. They also differ in their definition of family income as they use information on financial hardship as a measure of low-income. ${ }^{18}$ Although Khanam et al. (2009) use a similar set of control variables as our study, they use maternal subjective health as the proxy for parental health which correlates with subjective child health. However, we explore the role of subjective maternal health further in section 5.3.

Next, we add controls for housing characteristics. The OLS coefficient reduces to 0.139 suggesting that dampness in the house and local area characteristics explain part of the income gradient. Similar to Currie et al. (2007), we find that nutrition helps explain the income gradient as the estimated income coefficient reduces to to 0.142 with controls for nutrition. Adding 'behavioural problems' reduces the income coefficient to about 0.131 , close to the effect we find when adding parental health. Finally we control for all covariates jointly. The income coefficient remains significant at the $1 \%$ level and a doubling of income is associated with an improvement in child health of about 0.100 points. Our results demonstrate that these transmission mechanisms are important determinants of child health but do not fully explain the income gradient.

Column 2 presents the results once we instrument for income using the local unemployment rate. The key finding is that adding the transmission mechanisms to the base case specification hardly affects the size and statistical significance of the income coefficient. For instance, after

\footnotetext{
${ }^{18}$ However, the authors mention that the results are robust to using information from a banded income variable provided by the survey.
} 
adding parental health the instrumented income coefficient changes from 0.364 to 0.381 . Similar results apply to the addition of the other transmission mechanisms. The robustness of the income coefficient confirms the independence of the instrumental variables with respect to the control variables. Controlling for all covariates jointly, the causal effect of income is estimated at 0.374 which is almost identical to the coefficient obtained from the base case specification. The results show that income has a causal effect on child health where a doubling of income results in an improvement of child health of about 0.374 points according to the most extensive specification. As before, this estimate implies that a family needs to move from the bottom to the top end of the income distribution to increase child health by one point through changes in income.

Columns 3-6 in Panel B present the results for regressions by age of the child. The findings from the discussion of the pooled sample largely apply to these subgroups as well. Income continues to have a significant effect on child health for the subgroups. Given that the coefficients for the two age groups are never significantly different, we pool the age groups for the rest of the paper.

\subsection{What are we missing? Extended models of child health.}

We now explore whether three additional factors reduce the income effect: the presence of a chronic condition in the previous period; the presence of a current chronic condition; and the mother's subjective health. Although these variables are endogenous with respect to child health, we seek to examine whether the inclusion affects the estimated income coefficient. First, we want to rule out the possibility that the mother's current assessment of her child's health depends on the child's history of chronic illnesses. Second, the evaluation of subjective health may differ conditional on whether the child currently has a chronic illness. For instance, whether a child currently suffers from asthma is likely to affect a mother's evaluation of her child's health. Finally, a mother's assessment of her child's health may reflect and thus correlate with her own subjective health status. Results appear in Panel C of Table 1.

We first discuss the OLS results for the pooled sample. With the addition of the lagged chronic condition, the OLS coefficient reduces slightly from 0.150 to 0.143 and remains highly 
significant. Next, we control for the presence of a current chronic condition. The income coefficient reduces to 0.131 and remains significant. If the presence of a chronic condition fully explained a child's health status, the income coefficient should now be insignificant. The results thus imply that the subjective health assessment captures more information about a child's health apart from the presence of a chronic condition. Finally, we control for subjective maternal health. The addition of this single variable results in the largest reduction of the income coefficient to 0.095 , which is highly significant. Controlling for all variables used so far jointly, income still is significantly associated with child health. In contrast to Beam-Dowd (2007) and Khanam et al. (2009), our results do not confirm the hypothesis that subjective maternal health drives a spurious relationship between child health and family income.

Next we discuss the instrumented results. As before, the instrumented income coefficients are larger than the OLS coefficients. Second, controlling for each set of regressors individually, the instrumented income coefficients remain significant. However, the coefficients are not significantly different from each other and the key message remains the same - income continues to have a significant causal effect on child health even when conditioning on these other health covariates. The combined evidence from our OLS and 2SLS results show that income has a causal effect on child health that is not driven by one of these three factors.

\subsection{Exploring the effect at different ends of the health distribution}

So far we have examined the effect of income at the mean of child health. From a policy perspective, one might be more interested in the effect of income at the bottom end of the child health distribution: can changes in income move children from being health-poor to healthrich? We therefore generate a binary indicator equal to 1 if the child is reported to be in fair or poor health. Only $4 \%$ and $2.9 \%$ of children are health-poor at waves 3 and 4 , respectively. ${ }^{19}$ We proceed analogously to the previous section, the only difference being that we now estimate a linear probability model (LPM) due to the binary dependent variable for the pooled sample

\footnotetext{
${ }^{19}$ The results are robust to classifying the middle health category as 'poor' health as well. This increases the proportion of children in poor health from $4 \%$ to $16.7 \%$ at wave 3 , and from $2.9 \%$ to $11.9 \%$ at wave 4 . Although the coefficients increase in size, levels of significance remain the same and the key insights from the analysis do not change. Results available upon request.
} 
only. $^{20}$

\section{[Insert Table 2 here]}

The results from columns (1) and (2) presented in Table 2 are consistent with our previous analysis. The OLS estimates show that, regardless of the specification, an increase in income is significantly associated with a decrease in the probability of being in poor health. For the base case, a doubling of income is associated with a 1.9 percentage points reduction in the probability of being in poor health. The IV estimates are again larger in absolute size and significant at least at the $10 \%$ level in all specifications. Give the base case specification, a doubling of income lowers the probability of a child being in the bottom two categories by about 6.4 percentage points.

We also generate a binary indicator for being in excellent health. The results are presented in columns (3) and (4). The results clearly show that the effect of income is much stronger at the top end of the distribution. Given the base case specification, the IV estimates imply that a doubling of income increases the probability of a child being in the top health category by about 19 percentage points. This result is robust to the addition of the transmission mechanisms. With all controls in place, the doubling of income increases the probability by about 18.8 percentage points.

One potential explanation for the weaker effect found at the bottom end of the health distribution may be the existence of the National Health Service (NHS) which provides free universal health care. The free provision allows low-income families to seek medical treatment for their children independent of their income. Thus, the link between income and a child being in poor health may be mediated by the NHS. Although we cannot be certain about the role of the NHS, we conclude that the effect of income is stronger at the top rather than the bottom end of the distribution.

\footnotetext{
${ }^{20}$ For brevity we do not show the results for separate regressions by age of the child as the coefficients are never significantly different from each other. The results are available upon request.
} 


\subsection{Effect on chronic health conditions}

Having examined the effect of income on subjective child health, we now analyse the effect of income on two indicators reflecting chronic health conditions. If family income has only a small effect on subjective child health, and if the effect is located mainly at the top end of the health distribution, we would expect to see a small, if any, effect of income on the incidence of having a chronic condition. The MCS provides detailed information on children's health conditions which are coded according to the ICD-10 classification. Although this classification allows a detailed breakdown of diseases into different conditions, the proportion of children affected by these conditions is often fairly low (see Table A.4). For this reason, we generate two aggregate indicators using the information from Table A.4: whether the child currently has any long-standing condition; and whether the child currently has any limiting long-standing condition. We repeat the same analysis as earlier by estimating LPMs and present the tables separately for the two dependent variables.

\section{[Insert Table 3 here]}

Column 1 in Table 3 shows that income is significantly associated with a child having a longstanding condition given the base case specification. A doubling of family income is associated with a reduction in the probability of a child having a long-standing condition of about 2.3 percentage points. Income remains to be significantly correlated with child health with the addition of the transmission mechanisms. The only exception is parental health. Here we find that once we control for parental health, the association turns insignificant lending support to the hypothesis that parental health drives the relationship between income and child health. Once we control for all transmission mechanisms jointly, income is no longer significantly associated with child health.

From column 2 we see that these findings are largely confirmed once we instrument for income. Given a large sample size, a strong instrument in the first-stage $(\mathrm{F}=145.3)$, and that about $20 \%$ of children have a long-standing condition, we conclude that the effect should be estimated fairly precisely. That we do not find a significant effect on the incidence of a long-standing condition is consistent with our previous section and the results by Currie et al. (2007) who find no 
association between family income and objective measures of child health. Although the MCS does not provide information on whether these conditions are doctor-diagnosed, they are likely to be as the level of detail provided is fairly high. Part of the explanation that income does not have an effect may once more be attributed to the existence of the NHS which provides free care for children from both poor and rich families. ${ }^{21}$

Finally, we examine the effect of family income on the probability of a child having a limiting long-standing condition. Results are presented in columns 3-4 in Table 3. Once we control for the base case variables, both the OLS and IV estimates are small in size. Consistent with the previous results for having a chronic condition, we conclude that income does not have a causal effect on the probability of a child having a limiting long-standing condition.

\section{Robustness checks}

\subsection{Choice of instruments}

We now examine the robustness of the results to using different sets of instruments. In addition to the current unemployment rate (IV1), we use the following sets of instruments:

1. IV2: lagged unemployment rate (by one year);

2. IV3: unemployment rate and business growth rate;

3. IV4: unemployment rate, business growth rate, and regional GDI (gross domestic income per head);

4. IV5: occupational status of the child's grandparents.

The first three alternatives use regional labour market characteristics. Given that we expect these variables to correlate strongly with income, but exogenous to the child health equation, we believe these to be suitable instruments. The fourth alternative uses a completely different instrument - the occupation of the child's grandparents (see Maurin, 2002). To ensure the va-

\footnotetext{
${ }^{21}$ Once we estimate the model separately by age of the child, we find no evidence of an age gradient in income for objective child health. The coefficients for children aged 4-6 and 6-8 are never significantly different from each other. Results are available upon request.
} 
lidity of the exclusion restriction for this set of instruments, we include additional covariates to capture potentially problematic factors related to the grandparents. ${ }^{22}$

For each set of instruments, we perform a variety of diagnostic tests. Whenever the first stage is overidentified, the validity of the instruments is tested with the Sargan over-identification test. The results are presented in Table 4.

\section{[Insert Table 4 here]}

Reassuringly, the newly estimated coefficients are highly robust to the choice of instruments. All instruments are highly correlated with the income variables as indicated by the first-stage F-statistics. Furthermore, all overidentified models pass the Sargan overidentification test indicating that the instruments are correctly excluded from the first stage. The estimated income coefficients for the base case specification range from 0.267 (IV2) to 0.502 (IV5) and are all significantly different from zero. Not surprisingly, the size of the estimated income coefficient differs slightly between the specifications, as each specification uses different instruments and identifies different income variations. Yet, despite these differences, the general pattern and magnitude of estimated coefficients does not change with the inclusion of the transmission mechanisms. The occupational status is more sensitive to the inclusion of additional controls, particularly 'behavioural problems', indicating a stronger degree of correlation between the instrument and these transmission mechanisms. However, once we control for all transmission mechanisms, the size of the income effect for the final specification is close to the other instruments. The findings for alternative instruments clearly confirm the earlier finding that income has a small but significant causal effect on child health. ${ }^{23}$

\subsection{Instrument validity}

Our identification strategy rests on the assumption that the instrument does not correlate with the unobserved determinants of child health. The validity of the instrument is thus compromised

\footnotetext{
${ }^{22}$ These include: if the grandparents are still alive; if any of the grandparents live in the same household; and dummy variables for the frequency with which the grandparents see the children.

${ }^{23} \mathrm{As}$ an additional check, we re-estimated the overidentified models by limited information maximum likelihood (LIML) because 2SLS is not an unbiased estimator. Asymptotically, LIML has the same distribution as 2SLS, but LIML is median-unbiased and less biased in finite samples (Davidson and MacKinnon, 2004). The results clearly show that estimated coefficients obtained by LIML are almost identical to the coefficients from Table 4, confirming the robustness of the 2 SLS results for the overidentified models. The results are available upon request.
} 
if the instrument correlates with the unobserved determinants of child health. If this were the case, the instrument should also correlate with the unobserved determinants of other proxies of child health, for instance the child's birthweight. To examine this possibility, we perform a placebo-regression inspired by Frijters, Johnston, Shah, and Shields (2009) and regress a child's birthweight on the different instruments and the base case control variables. The instrument should be significant if it systematically correlates with the unobserved determinants of child health. The results presented in Table A.3 show that none of the local labour market instruments are significantly correlated with birthweight. These results suggest that the instruments derived from the local labour market characteristics do not correlate with unobserved determinants of child health. However, the occupation status of grandparents does correlate with birthweight. Without further control variables, the validity of the occupation status of the grandparents as an instrument is threatened.

\subsection{Reverse causality}

In addition to measurement error and unobserved heterogeneity, we are concerned about the issue of reverse causality. This might arise if mothers with ill children reduce their labour supply to look after their child and have lower earnings as a consequence. We follow Currie et al. (2007) and re-estimate the model for permanent income after excluding all children with a limiting long-standing condition. We assume that the labour supply of mothers will not be affected by the health of children that are not limited by any chronic conditions. The results presented in Table A.6 are very similar to the results discussed earlier. Although the coefficients are slightly closer to zero after dropping the children, they are not statistically different from the full sample. We conclude that reverse causality does not pose a major problem to our analysis.

\subsection{Permanent or current income?}

So far we examined the effect of permanent income on child health. Aside from addressing measurement error, there exists another theoretical reason for using permanent rather than current income: Case et al. (2002) hypothesise that families make health investment decisions on the basis of long-run average income rather than current income. This notion is analogous to the 
idea of consumption smoothing applied to investments in health. If this hypothesis is true, then the timing of income should not be important and the coefficients on current and permanent income on current child health should not be different. We therefore repeat the estimation of equations (2)-(5) for the pooled sample using current instead of permanent income. The results are presented in Table 5.

\section{[Insert Table 5 here]}

We first discuss the OLS results in the first column. First, as expected, the estimated coefficients are smaller than those using permanent income (see Table 1) due to measurement error. Given the base case specification, a $100 \%$ increase in current income improves child health by 0.093 points. That the point estimate for current income is statistically different from permanent income empirically supports the hypothesis that the timing of income matters. Second, adding the transmission mechanisms to the base case, we observe the same pattern as with permanent income - the income coefficient decreases, but remains significant in all specifications. Even with all controls in place, current income is significantly correlated with child health. These results support the notion that our results for permanent income are not driven by the definition of income.

Column 2 presents the results for the pooled sample instrumenting for income. The diagnostic tests show that the instrument correlated strongly with current income ( $\mathrm{F}=84.8)$. Again, the instrumented coefficients are larger than the coefficients obtained by OLS. For the base case specification, a doubling of income improves child health by about 0.423 points. This coefficient is not statistically significantly different from the instrumented coefficient for permanent income (0.364).

The 2SLS coefficients thus provide an entirely different conclusion as the instrumented coefficients for permanent and current income are not significantly different from each other. This is consistent with the idea that long-run average income rather than current income determines child health. The same finding applies when we add controls for the transmission mechanisms. Furthermore, the coefficient on current income again proves to be robust to the inclusion of the transmission mechanisms. This supports the exogeneity assumption made about the instru- 
ment. Controlling for all covariates jointly, a doubling of current income increases child health by 0.428 points. For permanent income, the effect of the same specification is 0.374 . Our results therefore provide novel and robust evidence that the timing of income appears not to matter in the UK. As a further robustness check, columns 3-6 demonstrate that these results are robust to the equivalisation of income, i.e. whether we take into account household size and composition. The coefficients for equivalised and non-equivalised income are almost identical.

Furthermore, the panel structure of the MCS allows us to investigate the issue from a different angle by examining the effects of past income on current child health. For instance, for children aged 4-6 (6-8) we can exploit three (four) lagged values of income. In our empirical approach, we regress current child health (separately by age group) using covariates from the base case specification and add controls for (current) income at different points in the child's life.

\section{[Insert Table 6 here]}

The results are shown in Table 6. Panel A presents the results for the OLS estimations, Panel B for the 2SLS estimations. The results in both panels show that lagged forms of income are significantly correlated with current child health. The coefficients on current income and previous income are, however, never significantly different from each other. This indicates a similar level of importance of income at different points in time. For instance, as seen in Panel A, the effect of income at birth (wave 1) on current health for children aged 4-6 is 0.090, which is not different from the effect of current income (0.104). The same finding applies to the instrumented results, although the coefficients are again larger in size. We confirm this pattern for older children, where the estimated coefficients on lagged income (waves 1-3) are remarkably similar: $0.080,0.065$, and 0.084 respectively. Our findings match the conclusion by Propper et al. (2007) who argue that the frequency - rather than the timing - of poverty matter most for child health. Combined with the previous result, i.e. that the effect of current income is not different from the effect of permanent income, our results provide further support to the hypothesis that the timing of income does not matter for child health in the UK. 


\section{Conclusion}

The present study examines the causal effect of family income on child health using an instrumental variables approach. We exploit exogenous variation in local labour market characteristics to instrument for income. The study extends the previous literature that has universally confirmed a positive association between parent-reported child health and family income. However, whether income has a causal effect on child health or whether the relationship is driven spuriously by unobserved variables is still unclear. In this study, we employ different sets of instrumental variables to identify the causal effect of family income on subjective and objective measures of child health. Furthermore, we exploit the rich socio-economic data from the Millennium Cohort Study to examine the transmission mechanisms through which income could affect child health. The study investigates the effect of family income on both subjective and objective indicators of child health.

The results provide novel evidence that income has a significant but very small causal effect on subjective child health in the UK. The results from our base case specification add substantially to our understanding of the relationship on two accounts: first, the difference between the OLS and IV estimates demonstrate large endogeneity biases for the OLS estimates. Second, our IV estimates provide evidence that income has a small but significant causal effect on subjective child health. We calculate that an increase in family income of about $274 \%$ is required to improve child health by one category. This is equivalent to moving from the 5 th to the 99th percentile of the income distribution. The effects is stronger at the top end of the health distribution. The NHS is one potential explanatory factor for the finding that income has a small effect that is stronger at the top end of the health distribution. Furthermore, and consistent with other studies for the UK, we do not find evidence of a steepening income gradient with the age of the child.

In the second part of the analysis we examine the transmission mechanisms through which family income could influence child health such as parental health, housing, foetal-origins, nutrition and parental smoking. We separately add each group of transmission mechanisms to the base case specification to identify how much of the income effect is mediated via this group. 
Parental health, behavioural problems and housing appear as the most important transmission mechanisms. In contrast to recent contributions by Propper et al. (2007) and Khanam et al. (2009), we do not find that the relationship becomes insignificant once we control for parental health. Instead, income remains significantly associated with subjective child health with the addition of all transmission mechanisms. These results are confirmed by the IV estimates. Adding potential transmission mechanisms hardly changes the instrumented income coefficient. This confirms the exogeneity of the instrument with regard to these control variables.

The study also investigates the effect of family income on two chronic indicators of child health. These include whether the child has a long-standing condition, and whether this condition is limiting. We find small and mostly insignificant effects of family income on either of these indicators of child health. This is consistent with previous research (Currie et al., 2007) who have raised the role played by the NHS as one potential explanatory factor. Seeing their evidence in combination with our instrumented results, we contribute to the body of evidence documenting that income does not have an effect on objectively measured child health in the UK.

All results pass a wide range of sensitivity tests, including five alternative sets of instrumental variables and different definitions of income (current versus permanent, equivalised versus non-equivalised). We have also shown that reverse causality does not bias our results. Furthermore, exploiting the panel structure and information on both current and permanent income we conclude that timing of income does not matter in the UK. This is consistent with the hypothesis that families base their investment decisions on long-run rather than current income. We provide first evidence that when we instrument for income, the coefficients on permanent and current income become almost identical. 


\section{References}

Almond, D. and J. Currie (2011). Killing me softly: The fetal origins hypothesis. The Journal of Economic Perspectives 25(3), 153-172.

Andriessen, J., B. Brunekreef, W. Roemer, et al. (1998). Home dampness and respiratory health status in european children. Clinical and Experimental Allergy 28, 1191-1200.

Angrist, J. and J. Pischke (2009). Mostly harmless econometrics. Princeton, NJ: Princeton University Press.

Atkinson, R. and K. Kintrea (2001). Disentangling area effects: evidence from deprived and non-deprived neighbourhoods. Urban studies 38(12), 2277-2298.

Barker, D. (1998). Mothers, babies and health in later life (2nd ed.). Edinburgh, UK: Churchill Livingstone.

Beam-Dowd, J. (2007). Early childhood origins of the income/health gradient: The role of maternal health behaviors. Social Science \& Medicine 65(6), $1202-1213$.

Bilger, M. and V. Carrieri (2013). Health in the cities: When the neighborhood matters more than income. Journal of Health Economics 32(1), 1 - 11.

Case, A., D. Lee, and C. Paxson (2008). The income gradient in children's health: A comment on Currie, Shields and Wheatley Price. Journal of Health Economics 27(3), 801-807.

Case, A., D. Lubotsky, and C. Paxson (2002). Economic status and health in childhood: The origins of the gradient. American Economic Review 92(5), 1308-1334.

Case, A., C. Paxson, and T. Vogl (2007). Socioeconomic status and health in childhood: A comment on Chen, Martin and Matthews. Social Science \& Medicine 64(4), 757-761.

Chen, E., A. D. Martin, and K. A. Matthews (2006). Socioeconomic status and health: Do gradients differ within childhood and adolescence? Social Science \& Medicine 62(9), 21612170 .

Cook, D. and D. Strachan (1999). Summary of effects of parental smoking on the respiratory health of children and implications for research. Thorax 54(4), 357-366.

Currie, A., M. A. Shields, and S. W. Price (2007). The child health/family income gradient: Evidence from England. Journal of Health Economics 26(2), 213 - 232.

Currie, J. (2009). Healthy, wealthy, and wise: Socioeconomic status, poor health in childhood, and human capital development. Journal of Economic Literature 47(1), 87-122.

Currie, J. and M. Stabile (2003). Socioeconomic status and child health: Why is the relationship stronger for older children? American Economic Review 93(5), 1813-1823.

Davidson, R. and J. MacKinnon (2004). Econometric theory and methods. New York, NY: Oxford Univ. Press.

Doyle, O., C. Harmon, and I. Walker (2007). The impact of parental income and education on child health. Further evidence for England. Working Papers 200706, Geary Institute, University College Dublin. 
Frijters, P., D. W. Johnston, M. Shah, and M. A. Shields (2009). To work or not to work? child development and maternal labor supply. American Economic Journal: Applied Economics, 97-110.

Fuchs, V. R. (1982). Time preference and health: An exploratory study. In Economic Aspects of Health, NBER Chapters, pp. 93-120. National Bureau of Economic Research, Inc.

Gilliland, F., Y. Li, and J. Peters (2001). Effects of maternal smoking during pregnancy and environmental tobacco smoke on asthma and wheezing in children. American journal of respiratory and critical care medicine 163(2), 429-436.

Gini, G. and T. Pozzoli (2009). Association between bullying and psychosomatic problems: A meta-analysis. Pediatrics 123(3), 1059-1065.

Gravelle, H. and M. Sutton (2003). Income related inequalities in self assessed health in Britain: 1979-1995. Journal of Epidemiology and Community Health 57(2), 125-129.

Gregg, P., E. Washbrook, C. Propper, and S. Burgess (2005). The effects of a mother's return to work decision on child development in the UK. Economic Journal 115(501), F48-F80.

Heckman, J. J. (2007). The economics, technology, and neuroscience of human capability formation. Proceedings of the National Academy of Sciences 104(33), 13250-13255.

Imbens, G. and J. Angrist (1994). Identification and estimation of local average treatment effects. Econometrica: Journal of the Econometric Society, 467-475.

Jacob, B. A., J. Ludwig, and D. L. Miller (2013). The effects of housing and neighborhood conditions on child mortality. Journal of Health Economics 32(1), 195 - 206.

Kelly, Y. and M. Bartley (2010). Parental and child health. Children of the 21st century: the first five years 2, 249-272.

Khanam, R., H. S. Nghiem, and L. B. Connelly (2009). Child health and the income gradient: Evidence from Australia. Journal of Health Economics 28(4), 805-817.

Long, L. (1972). The influence of mumber and ages of children on residential mobility. Demography 9(3), 371-382.

Maurin, E. (2002). The impact of parental income on early schooling transitions: A reexamination using data over three generations. Journal of Public Economics 85(3), 301-332.

Mincer, J. (1977). Family migration decisions. National Bureau of Economic Research Cambridge, Mass., USA.

Mundlak, Y. (1978). On the pooling of time series and cross section data. Econometrica 46(1), 69-85.

Paul, K. I. and K. Moser (2009). Unemployment impairs mental health: Meta-analyses. Journal of Vocational Behavior 74(3), 264 - 282.

Peat, J., J. Dickerson, and J. Li (2007). Effects of damp and mould in the home on respiratory health: a review of the literature. Allergy 53(2), 120-128. 
Propper, C., J. Rigg, and S. Burgess (2007). Child health: evidence on the roles of family income and maternal mental health from a UK birth cohort. Health Economics 16(11), 12451269.

Ravelli, A., J. van der Meulen, R. Michels, C. Osmond, D. Barker, C. Hales, O. Bleker, et al. (1998). Glucose tolerance in adults after prenatal exposure to famine. Lancet 351(9097), $173-177$.

Reinhold, S. and H. Jürges (2012). Parental income and child health in Germany. Health Economics 21(5), 562-579.

$\mathrm{Xu}, \mathrm{X}$. and R. Kaestner (2010). The business cycle and health behaviors. Technical report, National Bureau of Economic Research. 
Figure 1: Distribution of child health status - by wave

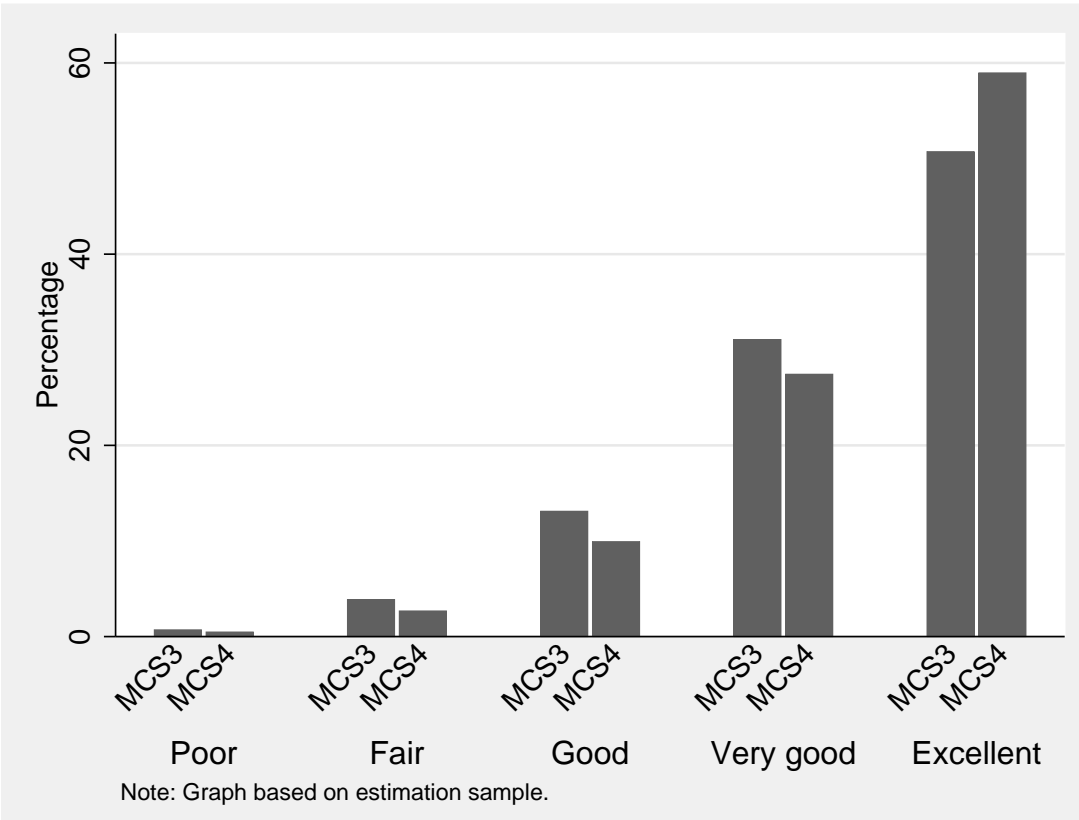

Figure 2: Distribution of child health status - by income quartiles

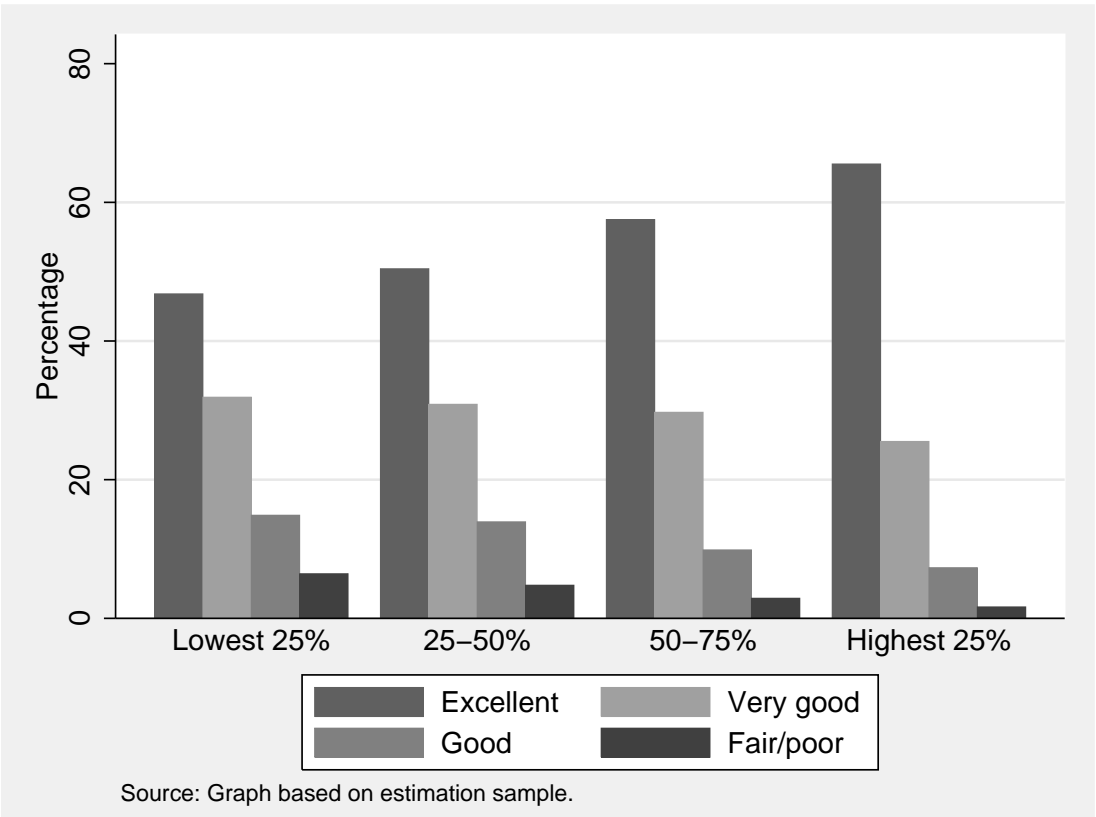


Table 1: The effect of permanent income on self-reported health of a child.

\begin{tabular}{|c|c|c|c|c|c|c|}
\hline \multirow[b]{2}{*}{ Controls } & \multicolumn{2}{|c|}{ Pooled sample } & \multicolumn{2}{|c|}{ Age 4-6 } & \multicolumn{2}{|c|}{ Age 6-8 } \\
\hline & $\begin{array}{l}\text { OLS } \\
(1)\end{array}$ & $\begin{array}{l}\text { IV } \\
\text { (2) }\end{array}$ & $\begin{array}{l}\text { OLS } \\
(3)\end{array}$ & $\begin{array}{l}\text { IV } \\
\text { (4) }\end{array}$ & $\begin{array}{l}\text { OLS } \\
(5)\end{array}$ & $\begin{array}{l}\text { IV } \\
\text { (6) }\end{array}$ \\
\hline \multicolumn{7}{|l|}{ PANEL A: } \\
\hline No controls & $\begin{array}{c}0.243 * * * \\
(0.010)\end{array}$ & $\begin{array}{c}0.504 * * * \\
(0.036)\end{array}$ & $\begin{array}{c}0.246 * * * \\
(0.012)\end{array}$ & $\begin{array}{c}0.439 * * * \\
(0.046)\end{array}$ & $\begin{array}{c}0.235^{* * * *} \\
(0.012)\end{array}$ & $\begin{array}{c}0.438 * * * \\
(0.041)\end{array}$ \\
\hline Base case & $\begin{array}{c}0.150^{* * * *} \\
(0.015)\end{array}$ & $\begin{array}{c}0.364 * * \\
(0.144)\end{array}$ & $\begin{array}{c}0.158 * * * \\
(0.020)\end{array}$ & $\begin{array}{c}0.377 * * \\
(0.171)\end{array}$ & $\begin{array}{c}0.141 * * * \\
(0.018)\end{array}$ & $\begin{array}{c}0.390^{* *} \\
(0.180)\end{array}$ \\
\hline \multicolumn{7}{|c|}{ PANEL B: Base case plus controls for } \\
\hline Parental health & $\begin{array}{c}0.129 * * * \\
(0.015)\end{array}$ & $\begin{array}{c}0.381 * * * \\
(0.143)\end{array}$ & $\begin{array}{c}0.138 * * * \\
(0.020)\end{array}$ & $\begin{array}{c}0.401 * * \\
(0.170)\end{array}$ & $\begin{array}{c}0.118 * * * \\
(0.019)\end{array}$ & $\begin{array}{c}0.401 * * \\
(0.179)\end{array}$ \\
\hline Housing & $\begin{array}{c}0.139 * * * \\
(0.016)\end{array}$ & $\begin{array}{c}0.358^{* *} \\
(0.150)\end{array}$ & $\begin{array}{c}0.149 * * * \\
(0.020)\end{array}$ & $\begin{array}{c}0.372 * * \\
(0.178)\end{array}$ & $\begin{array}{c}0.128 * * * \\
(0.019)\end{array}$ & $\begin{array}{c}0.388^{* *} \\
(0.188)\end{array}$ \\
\hline Foetal origins & $\begin{array}{c}0.148 * * * \\
(0.015)\end{array}$ & $\begin{array}{c}0.384 * * * \\
(0.144)\end{array}$ & $\begin{array}{c}0.156^{* * * *} \\
(0.019)\end{array}$ & $\begin{array}{c}0.398 * * \\
(0.171)\end{array}$ & $\begin{array}{c}0.139 * * * \\
(0.018)\end{array}$ & $\begin{array}{c}0.410 * * \\
(0.183)\end{array}$ \\
\hline Nutrition & $\begin{array}{c}0.142 * * * \\
(0.015)\end{array}$ & $\begin{array}{c}0.345^{* *} \\
(0.144)\end{array}$ & $\begin{array}{c}0.149 * * * \\
(0.020)\end{array}$ & $\begin{array}{c}0.352 * * \\
(0.172)\end{array}$ & $\begin{array}{c}0.135^{* * * *} \\
(0.019)\end{array}$ & $\begin{array}{c}0.384 * * \\
(0.180)\end{array}$ \\
\hline Parental smoking & $\begin{array}{c}0.144 * * * \\
(0.015)\end{array}$ & $\begin{array}{c}0.368 * * * \\
(0.143)\end{array}$ & $\begin{array}{c}0.152 * * * \\
(0.020)\end{array}$ & $\begin{array}{c}0.372 * * \\
(0.171)\end{array}$ & $\begin{array}{c}0.135 * * * \\
(0.018)\end{array}$ & $\begin{array}{c}0.397 * * \\
(0.178)\end{array}$ \\
\hline Behavioural problems & $\begin{array}{c}0.131 * * * \\
(0.015)\end{array}$ & $\begin{array}{c}0.353^{* *} \\
(0.143)\end{array}$ & $\begin{array}{c}0.138^{* * * *} \\
(0.019)\end{array}$ & $\begin{array}{c}0.359^{* *} \\
(0.171)\end{array}$ & $\begin{array}{c}0.122 * * * \\
(0.018)\end{array}$ & $\begin{array}{c}0.389 * * \\
(0.179)\end{array}$ \\
\hline All jointly & $\begin{array}{c}0.100 * * * \\
(0.016)\end{array}$ & $\begin{array}{c}0.374 * * \\
(0.147)\end{array}$ & $\begin{array}{c}0.107 * * * \\
(0.020)\end{array}$ & $\begin{array}{c}0.382 * * \\
(0.176)\end{array}$ & $\begin{array}{c}0.091 * * * \\
(0.019)\end{array}$ & $\begin{array}{c}0.412 * * \\
(0.186)\end{array}$ \\
\hline \multicolumn{7}{|c|}{ PANEL C: Base case plus controls for } \\
\hline Lagged chronic condition & $\begin{array}{c}0.143 * * * \\
(0.015)\end{array}$ & $\begin{array}{c}0.366^{* * * *} \\
(0.137)\end{array}$ & $\begin{array}{c}0.156^{* * * *} \\
(0.019)\end{array}$ & $\begin{array}{c}0.402^{* *} \\
(0.169)\end{array}$ & $\begin{array}{c}0.128 * * * \\
(0.018)\end{array}$ & $\begin{array}{c}0.364 * * \\
(0.174)\end{array}$ \\
\hline Child chronic condition & $\begin{array}{c}0.131 * * * \\
(0.014)\end{array}$ & $\begin{array}{c}0.329 * * * \\
(0.126)\end{array}$ & $\begin{array}{c}0.137 * * * \\
(0.018)\end{array}$ & $\begin{array}{c}0.330 * * \\
(0.156)\end{array}$ & $\begin{array}{c}0.124 * * * \\
(0.017)\end{array}$ & $\begin{array}{c}0.354 * * \\
(0.162)\end{array}$ \\
\hline Maternal health & $\begin{array}{c}0.095^{* * * *} \\
(0.015) \\
\end{array}$ & $\begin{array}{c}0.349 * * \\
(0.137)\end{array}$ & $\begin{array}{c}0.102 * * * \\
(0.019)\end{array}$ & $\begin{array}{c}0.386^{* *} \\
(0.164) \\
\end{array}$ & $\begin{array}{c}0.086^{* * * *} \\
(0.018)\end{array}$ & $\begin{array}{l}0.336^{*} \\
(0.174)\end{array}$ \\
\hline All jointly & $\begin{array}{c}0.071^{* * *} * \\
(0.013) \\
\end{array}$ & $\begin{array}{c}0.312^{* * *} \\
(0.125) \\
\end{array}$ & $\begin{array}{c}0.073 * * * \\
(0.018) \\
\end{array}$ & $\begin{array}{c}0.341^{* *} \\
(0.157) \\
\end{array}$ & $\begin{array}{c}0.067 * * * \\
(0.017) \\
\end{array}$ & $\begin{array}{l}0.294 * \\
(0.162) \\
\end{array}$ \\
\hline $\mathrm{N}$ & 22142 & 22142 & 11590 & 11590 & 10552 & 10552 \\
\hline
\end{tabular}

Notes: Each coefficient represents a separate regression. Variables included in each specification are listed in Table A.1. IV uses local unemployment rate as instrumental variable. Cluster-robust standard errors in parentheses. $* * * p<0.01, * * p<0.05, * p<0.1$. First-stage $F$ values and underidentification test statistics for each regression are listed in table A.5. 
Table 2: Linear probability model: the effect of permanent income on the probability of a child being in the top/bottom health categories.

\begin{tabular}{|c|c|c|c|c|}
\hline \multirow[b]{2}{*}{ Controls } & \multicolumn{2}{|c|}{ Poor health } & \multicolumn{2}{|c|}{ Excellent health } \\
\hline & $\begin{array}{l}\text { OLS } \\
\text { (1) }\end{array}$ & $\begin{array}{l}\text { IV } \\
\text { (2) }\end{array}$ & $\begin{array}{l}\text { OLS } \\
(3)\end{array}$ & $\begin{array}{l}\text { IV } \\
\text { (4) }\end{array}$ \\
\hline No controls & $\begin{array}{c}-0.030 * * * \\
(0.002)\end{array}$ & $\begin{array}{c}-0.056 * * * \\
(0.008)\end{array}$ & $\begin{array}{c}0.126 * * * \\
(0.006)\end{array}$ & $\begin{array}{c}0.260 * * * * \\
(0.020)\end{array}$ \\
\hline Base case & $\begin{array}{c}-0.019 * * * * \\
(0.003)\end{array}$ & $\begin{array}{c}-0.064 * * \\
(0.032)\end{array}$ & $\begin{array}{c}0.088^{* * * *} \\
(0.009)\end{array}$ & $\begin{array}{c}0.190 * * \\
(0.082)\end{array}$ \\
\hline \multicolumn{5}{|c|}{ Base case plus controls for } \\
\hline Parental health & $\begin{array}{c}-0.016^{* * * *} \\
(0.003)\end{array}$ & $\begin{array}{c}-0.066 * * \\
(0.032)\end{array}$ & $\begin{array}{c}0.077 * * * \\
(0.009)\end{array}$ & $\begin{array}{c}0.198 * * \\
(0.082)\end{array}$ \\
\hline Housing & $\begin{array}{c}-0.017 * * * \\
(0.003)\end{array}$ & $\begin{array}{c}-0.064 * \\
(0.033)\end{array}$ & $\begin{array}{c}0.084 * * * \\
(0.009)\end{array}$ & $\begin{array}{c}0.188 * * \\
(0.085)\end{array}$ \\
\hline Foetal origins & $\begin{array}{c}-0.018 * * * \\
(0.003)\end{array}$ & $\begin{array}{c}-0.066 * * \\
(0.032)\end{array}$ & $\begin{array}{c}0.087 * * * \\
(0.009)\end{array}$ & $\begin{array}{c}0.200 * * \\
(0.083)\end{array}$ \\
\hline Nutrition & $\begin{array}{c}-0.018 * * * \\
(0.003)\end{array}$ & $\begin{array}{c}-0.066 * * \\
(0.032)\end{array}$ & $\begin{array}{c}0.084 * * * \\
(0.009)\end{array}$ & $\begin{array}{c}0.172 * * \\
(0.082)\end{array}$ \\
\hline Parental smoking & $\begin{array}{c}-0.018 * * * \\
(0.003)\end{array}$ & $\begin{array}{c}-0.066 * * \\
(0.032)\end{array}$ & $\begin{array}{c}0.085^{* * * *} \\
(0.009)\end{array}$ & $\begin{array}{c}0.191 * * \\
(0.082)\end{array}$ \\
\hline Behavioural problems & $\begin{array}{c}-0.016^{* * * *} \\
(0.003)\end{array}$ & $\begin{array}{l}-0.063^{*} \\
(0.032)\end{array}$ & $\begin{array}{c}0.079 * * * \\
(0.009)\end{array}$ & $\begin{array}{c}0.185^{* *} \\
(0.082)\end{array}$ \\
\hline All jointly & $\begin{array}{c}-0.012 * * * \\
(0.003)\end{array}$ & $\begin{array}{c}-0.069 * * \\
(0.033)\end{array}$ & $\begin{array}{c}0.064 * * * \\
(0.009)\end{array}$ & $\begin{array}{r}0.188^{* *} \\
(0.085)\end{array}$ \\
\hline $\mathrm{N}$ & 22142 & 22142 & 22142 & 22142 \\
\hline
\end{tabular}

Notes: Each coefficient represents a separate regression. Variables included in each specification are listed in Table A.1. IV uses local unemployment rate as instrumental variable. Cluster-robust standard errors in parentheses. $* * * p<0.01, * * p<0.05, * p<0.1$. 
Table 3: Linear probability model: the effect of permanent income on the probability of a child having a chronic health condition.

\begin{tabular}{|c|c|c|c|c|}
\hline \multirow[b]{2}{*}{ Controls } & \multicolumn{2}{|c|}{ Chronic condition } & \multicolumn{2}{|c|}{ Limiting chronic condition } \\
\hline & $\begin{array}{l}\text { OLS } \\
\text { (1) }\end{array}$ & $\begin{array}{l}\text { IV } \\
(2)\end{array}$ & $\begin{array}{l}\text { OLS } \\
\text { (3) }\end{array}$ & $\begin{array}{l}\text { IV } \\
\text { (4) }\end{array}$ \\
\hline No controls & $\begin{array}{c}-0.040 * * * \\
(0.005)\end{array}$ & $\begin{array}{l}-0.013 \\
(0.016)\end{array}$ & $\begin{array}{c}-0.025^{* * *} \\
(0.003)\end{array}$ & $\begin{array}{c}-0.024 * * \\
(0.010)\end{array}$ \\
\hline Base case & $\begin{array}{c}-0.023 * * * \\
(0.007)\end{array}$ & $\begin{array}{l}-0.023 \\
(0.066)\end{array}$ & $\begin{array}{c}-0.009 * * \\
(0.004)\end{array}$ & $\begin{array}{l}-0.035 \\
(0.040)\end{array}$ \\
\hline $\begin{array}{l}\text { Diagnostic tests for base cas } \\
\text { Underidentification statistic } \\
\text { Underidentification p-value } \\
\text { First-stage F }\end{array}$ & pecification: & $\begin{array}{c}152.740 \\
0.000 \\
158.603\end{array}$ & & $\begin{array}{c}152.740 \\
0.000 \\
158.603\end{array}$ \\
\hline $\begin{array}{l}\text { Base case plus controls for } \\
\text { Parental health }\end{array}$ & $\begin{array}{l}-0.012 \\
(0.007)\end{array}$ & $\begin{array}{l}-0.036 \\
(0.066)\end{array}$ & $\begin{array}{l}-0.004 \\
(0.004)\end{array}$ & $\begin{array}{l}-0.040 \\
(0.040)\end{array}$ \\
\hline Housing & $\begin{array}{c}-0.019 * * \\
(0.007)\end{array}$ & $\begin{array}{l}-0.018 \\
(0.069)\end{array}$ & $\begin{array}{l}-0.008 * \\
(0.004)\end{array}$ & $\begin{array}{l}-0.034 \\
(0.042)\end{array}$ \\
\hline Foetal origins & $\begin{array}{l}-0.023 * * * \\
(0.007)\end{array}$ & $\begin{array}{l}-0.036 \\
(0.067)\end{array}$ & $\begin{array}{c}-0.009 * * \\
(0.004)\end{array}$ & $\begin{array}{l}-0.041 \\
(0.041)\end{array}$ \\
\hline Nutrition & $\begin{array}{l}-0.023 * * * \\
(0.007)\end{array}$ & $\begin{array}{l}-0.030 \\
(0.067)\end{array}$ & $\begin{array}{c}-0.009 * * \\
(0.004)\end{array}$ & $\begin{array}{l}-0.040 \\
(0.041)\end{array}$ \\
\hline Parental smoking & $\begin{array}{c}-0.022 * * * \\
(0.007)\end{array}$ & $\begin{array}{l}-0.025 \\
(0.066)\end{array}$ & $\begin{array}{l}-0.008^{*} \\
(0.004)\end{array}$ & $\begin{array}{l}-0.036 \\
(0.040)\end{array}$ \\
\hline Behavioural problems & $\begin{array}{c}-0.018 * * \\
(0.007)\end{array}$ & $\begin{array}{l}-0.020 \\
(0.066)\end{array}$ & $\begin{array}{l}-0.005 \\
(0.004)\end{array}$ & $\begin{array}{l}-0.033 \\
(0.040)\end{array}$ \\
\hline All jointly & $\begin{array}{l}-0.006 \\
(0.007)\end{array}$ & $\begin{array}{l}-0.049 \\
(0.068)\end{array}$ & $\begin{array}{l}-0.000 \\
(0.004)\end{array}$ & $\begin{array}{l}-0.049 \\
(0.042)\end{array}$ \\
\hline $\mathrm{N}$ & 22142 & 22142 & 22142 & 22142 \\
\hline
\end{tabular}

Notes: Each coefficient represents a separate regression. Variables included in each specification are listed in Table A.1. Underidentification test=Kleibergen-Paap test; First-stage F refers to F test of excluded instruments in the first stage. IV uses local unemployment rate as instrumental variable. Cluster-robust standard errors in parentheses. $* * * p<0.01$, ** $p<0.05, * p<0.1$. 
Table 4: Sensitivity analysis - using different instruments (2SLS) with permanent income. Pooled sample.

\begin{tabular}{|c|c|c|c|c|c|}
\hline Controls & $\begin{array}{c}\text { IV1 } \\
(1)\end{array}$ & $\begin{array}{l}\text { IV2 } \\
\text { (2) }\end{array}$ & $\begin{array}{c}\text { IV3 } \\
\text { (3) }\end{array}$ & $\begin{array}{c}\text { IV4 } \\
(4)\end{array}$ & $\begin{array}{l}\text { IV5 } \\
(5)\end{array}$ \\
\hline No controls & $\begin{array}{c}0.504 * * * \\
(0.036)\end{array}$ & $\begin{array}{c}0.445^{* * * *} \\
(0.037)\end{array}$ & $\begin{array}{c}0.513 * * * \\
(0.035)\end{array}$ & $\begin{array}{c}0.444 * * * \\
(0.034)\end{array}$ & $\begin{array}{c}0.367 * * * \\
(0.020)\end{array}$ \\
\hline Base case & $\begin{array}{c}0.364 * * \\
(0.144)\end{array}$ & $\begin{array}{c}0.267^{*} \\
(0.139)\end{array}$ & $\begin{array}{c}0.375^{* * * *} \\
(0.140)\end{array}$ & $\begin{array}{c}0.307 * * \\
(0.124)\end{array}$ & $\begin{array}{c}0.502 * * * \\
(0.105)\end{array}$ \\
\hline $\begin{array}{l}\text { Diagnostic tests for base cas } \\
\text { Underidentification statistic } \\
\text { Underidentification p-value } \\
\text { First-stage F } \\
\text { Sargan statistic } \\
\text { Sargan p-value }\end{array}$ & $\begin{array}{c}\text { ecification } \\
152.740 \\
0.000 \\
158.603\end{array}$ & $\begin{array}{c}158.623 \\
0.000 \\
164.541\end{array}$ & $\begin{array}{c}162.410 \\
0.000 \\
84.433 \\
0.579 \\
0.447\end{array}$ & $\begin{array}{c}205.165 \\
0.000 \\
71.788 \\
1.818 \\
0.403\end{array}$ & $\begin{array}{c}265.909 \\
0.000 \\
39.580 \\
5.169 \\
0.522\end{array}$ \\
\hline $\begin{array}{l}\text { Base case plus controls for } \\
\text { Parental health }\end{array}$ & $\begin{array}{c}0.381 * * * \\
(0.143)\end{array}$ & $\begin{array}{c}0.284 * * \\
(0.138)\end{array}$ & $\begin{array}{c}0.389 * * * \\
(0.139)\end{array}$ & $\begin{array}{c}0.312 * * \\
(0.123)\end{array}$ & $\begin{array}{c}0.462 * * * \\
(0.107)\end{array}$ \\
\hline Housing & $\begin{array}{c}0.358^{* *} \\
(0.150)\end{array}$ & $\begin{array}{l}0.256^{*} \\
(0.146)\end{array}$ & $\begin{array}{c}0.373 * * * \\
(0.144)\end{array}$ & $\begin{array}{c}0.302 * * \\
(0.126)\end{array}$ & $\begin{array}{c}0.518 * * * \\
(0.114)\end{array}$ \\
\hline Foetal origins & $\begin{array}{c}0.384 * * * \\
(0.144)\end{array}$ & $\begin{array}{c}0.287 * * \\
(0.139)\end{array}$ & $\begin{array}{c}0.395 * * * \\
(0.141)\end{array}$ & $\begin{array}{c}0.333 * * * \\
(0.125)\end{array}$ & $\begin{array}{c}0.482 * * * \\
(0.106)\end{array}$ \\
\hline Nutrition & $\begin{array}{c}0.345^{* *} \\
(0.144)\end{array}$ & $\begin{array}{l}0.252^{*} \\
(0.139)\end{array}$ & $\begin{array}{c}0.358^{* *} \\
(0.141)\end{array}$ & $\begin{array}{c}0.297 * * \\
(0.124)\end{array}$ & $\begin{array}{c}0.471 * * * * \\
(0.106)\end{array}$ \\
\hline Parental smoking & $\begin{array}{c}0.368 * * * \\
(0.143)\end{array}$ & $\begin{array}{c}0.272 \text { ** } \\
(0.138)\end{array}$ & $\begin{array}{c}0.382 * * * \\
(0.139)\end{array}$ & $\begin{array}{c}0.313^{* *} \\
(0.123)\end{array}$ & $\begin{array}{c}0.487 * * * * \\
(0.106)\end{array}$ \\
\hline Behavioural problems & $\begin{array}{c}0.353 * * \\
(0.143)\end{array}$ & $\begin{array}{l}0.252^{*} \\
(0.138)\end{array}$ & $\begin{array}{c}0.365 * * * \\
(0.139)\end{array}$ & $\begin{array}{c}0.294 * * \\
(0.123)\end{array}$ & $\begin{array}{c}0.434 * * * \\
(0.105)\end{array}$ \\
\hline All jointly & $\begin{array}{c}0.374 * * \\
(0.147)\end{array}$ & $\begin{array}{l}0.276^{*} \\
(0.143)\end{array}$ & $\begin{array}{c}0.388 * * * \\
(0.142)\end{array}$ & $\begin{array}{c}0.314^{* *} \\
(0.124)\end{array}$ & $\begin{array}{c}0.371 * * * * \\
(0.117)\end{array}$ \\
\hline $\mathrm{N}$ & 22142 & 22142 & 22099 & 22099 & 22140 \\
\hline
\end{tabular}

Notes: Each coefficient represents a separate regression. Variables included in each specification are listed in Table A.1. Underidentification test=Kleibergen-Paap test; First-stage F refers to F test of excluded instruments in the first stage. Cluster-robust standard errors in parentheses. $* * * p<0.01, * *$ $p<0.05, * p<0.1$.

Instruments used: IV1: local unemployment rate. IV2: lagged local unemployment rate (t-1).IV3: unemployment rate and business growth rate. IV4: unemployment rate, business growth rate, and regional GDI (gross domestic income per head). IV5: occupational status of the child's grandparents. 
Table 5: Sensitivity: using different definitions of income.

\begin{tabular}{|c|c|c|c|c|c|c|}
\hline \multirow[b]{3}{*}{ Controls } & & & \multicolumn{4}{|c|}{ Equivalised income } \\
\hline & \multicolumn{2}{|c|}{ Current Income } & \multicolumn{2}{|c|}{ Current Income } & \multicolumn{2}{|c|}{ Permanent Income } \\
\hline & $\begin{array}{l}\text { OLS } \\
\text { (1) }\end{array}$ & $\begin{array}{l}\text { IV } \\
(2)\end{array}$ & $\begin{array}{l}\text { OLS } \\
\text { (3) }\end{array}$ & $\begin{array}{l}\text { IV } \\
(4)\end{array}$ & $\begin{array}{l}\text { OLS } \\
\text { (5) }\end{array}$ & $\begin{array}{l}\text { IV } \\
(6)\end{array}$ \\
\hline No controls & $\begin{array}{l}0.185^{* * * *} \\
(0.008)\end{array}$ & $\begin{array}{l}0.497 * * * \\
(0.036)\end{array}$ & $\begin{array}{l}0.202 * * * \\
(0.009)\end{array}$ & $\begin{array}{l}0.493 * * * \\
(0.035)\end{array}$ & $\begin{array}{l}0.263 * * * \\
(0.010)\end{array}$ & $\begin{array}{l}0.494 * * * \\
(0.035)\end{array}$ \\
\hline Base case & $\begin{array}{l}0.093 * * * \\
(0.012)\end{array}$ & $\begin{array}{l}0.423 * * \\
(0.168)\end{array}$ & $\begin{array}{l}0.093 * * * \\
(0.012)\end{array}$ & $\begin{array}{l}0.415^{* *} \\
(0.165)\end{array}$ & $\begin{array}{l}0.153^{* * *} \\
(0.016)\end{array}$ & $\begin{array}{l}0.360 * * \\
(0.142)\end{array}$ \\
\hline $\begin{array}{l}\text { Underidentification statistic } \\
\text { Underidentification p-value } \\
\text { First-stage F }\end{array}$ & & $\begin{array}{l}83.602 \\
0.000 \\
84.875\end{array}$ & & $\begin{array}{l}85.673 \\
0.000 \\
87.024\end{array}$ & & $\begin{array}{l}156.021 \\
0.000 \\
162.279\end{array}$ \\
\hline \multicolumn{7}{|l|}{ Base case plus controls for } \\
\hline Parental health & $\begin{array}{l}0.082 * * * \\
(0.012)\end{array}$ & $\begin{array}{l}0.438 * * * \\
(0.166)\end{array}$ & $\begin{array}{l}0.082 * * * \\
(0.012)\end{array}$ & $\begin{array}{l}0.431 * * * \\
(0.163)\end{array}$ & $\begin{array}{l}0.132 * * * \\
(0.016)\end{array}$ & $\begin{array}{l}0.377 * * * \\
(0.141)\end{array}$ \\
\hline Housing & $\begin{array}{l}0.086 * * * \\
(0.012)\end{array}$ & $\begin{array}{l}0.414 * * \\
(0.175)\end{array}$ & $\begin{array}{l}0.086 * * * \\
(0.012)\end{array}$ & $\begin{array}{l}0.407 * * \\
(0.171)\end{array}$ & $\begin{array}{l}0.143^{* * *} \\
(0.016)\end{array}$ & $\begin{array}{l}0.353^{* *} \\
(0.148)\end{array}$ \\
\hline Foetal origins & $\begin{array}{l}0.092 * * * \\
(0.012)\end{array}$ & $\begin{array}{l}0.444 * * * \\
(0.169)\end{array}$ & $\begin{array}{l}0.092 * * * \\
(0.012)\end{array}$ & $\begin{array}{l}0.436 * * * \\
(0.166)\end{array}$ & $\begin{array}{l}0.151 * * * \\
(0.015)\end{array}$ & $\begin{array}{l}0.380 * * * \\
(0.143)\end{array}$ \\
\hline Nutrition & $\begin{array}{l}0.089 * * * \\
(0.012)\end{array}$ & $\begin{array}{l}0.400 * * \\
(0.168)\end{array}$ & $\begin{array}{l}0.089 * * * \\
(0.012)\end{array}$ & $\begin{array}{l}0.394 * * \\
(0.165)\end{array}$ & $\begin{array}{l}0.145^{* * * *} \\
(0.016)\end{array}$ & $\begin{array}{l}0.341^{* *} \\
(0.142)\end{array}$ \\
\hline Parental smoking & $\begin{array}{l}0.090 * * * \\
(0.012)\end{array}$ & $\begin{array}{l}0.429 * * \\
(0.168)\end{array}$ & $\begin{array}{l}0.090 * * * \\
(0.012)\end{array}$ & $\begin{array}{l}0.422 * * \\
(0.165)\end{array}$ & $\begin{array}{l}0.147 * * * \\
(0.016)\end{array}$ & $\begin{array}{l}0.364 * * * \\
(0.141)\end{array}$ \\
\hline Behavioural problems & $\begin{array}{l}0.084 * * * \\
(0.012)\end{array}$ & $\begin{array}{l}0.410^{* *} \\
(0.167)\end{array}$ & $\begin{array}{l}0.084 * * * \\
(0.012)\end{array}$ & $\begin{array}{l}0.403^{* *} \\
(0.164)\end{array}$ & $\begin{array}{l}0.135 * * * \\
(0.015)\end{array}$ & $\begin{array}{l}0.349 * * \\
(0.141)\end{array}$ \\
\hline All jointly & $\begin{array}{l}0.067 * * * \\
(0.012)\end{array}$ & $\begin{array}{l}0.428^{* *} \\
(0.170)\end{array}$ & $\begin{array}{l}0.067 * * * \\
(0.012)\end{array}$ & $\begin{array}{l}0.421 * * \\
(0.167)\end{array}$ & $\begin{array}{l}0.103 * * * \\
(0.016)\end{array}$ & $\begin{array}{l}0.370^{* *} \\
(0.145)\end{array}$ \\
\hline $\mathrm{N}$ & 22142 & 22142 & 22142 & 22142 & 22142 & 22142 \\
\hline
\end{tabular}

Notes: Each coefficient represents a separate regression. Variables included in each specification are listed in Table A.1. Underidentification test=Kleibergen-Paap test; First-stage F refers to F test of excluded instruments in the first stage. IV uses local unemployment rate as instrumental variable. Cluster-robust standard errors in parentheses. $* * * p<0.01, * * p<0.05, * p<0.1$. 


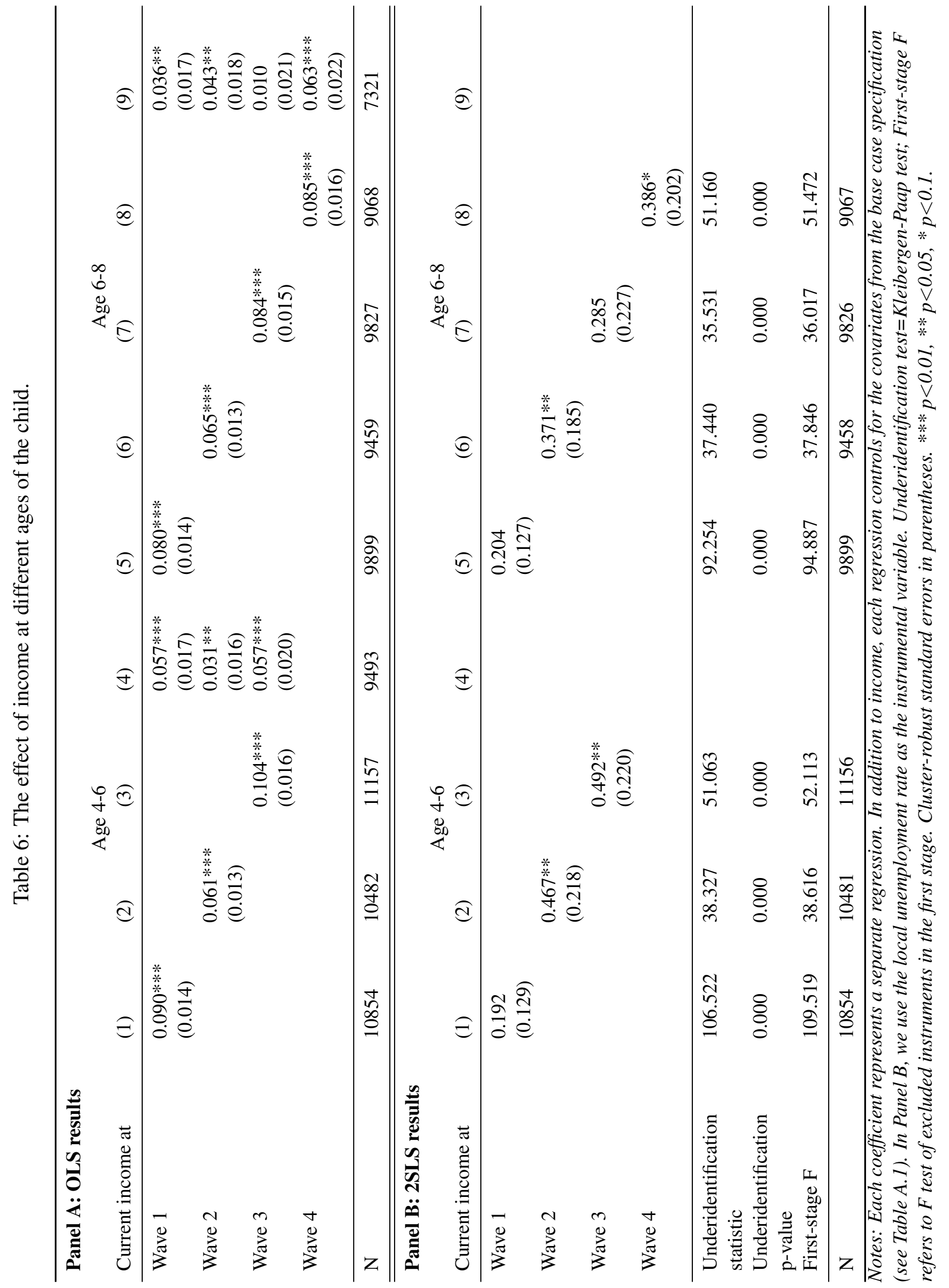


APPENDIX A 
Table A.1: Variables used in analysis

\begin{tabular}{|c|c|}
\hline \multicolumn{2}{|l|}{ Specification } \\
\hline Base case & $\begin{array}{l}\text { Family composition: log of household size; Dummy - biological father not } \\
\text { in the household } \\
\text { Child characteristics : age; age squared; sex; ethnicity; height (cm) } \\
\text { Mother's characteristics : age; height; } \\
\text { Regional indicators: set of regional dummies; urban dummy } \\
\text { Parental education: dummies for highest educational attainment (any } \\
\text { degree; A-level up to diploma; O-level to GSCE grades C; GCSE grade D } \\
\text { and below); dummy if education is missing } \\
\text { Parental employment: dummy if mother/father works; dummy if work } \\
\text { status is missing }\end{array}$ \\
\hline Parental health & $\begin{array}{l}\text { Maternal health: BMI; dummy - longstanding illness; dummy - limiting } \\
\text { longstanding illness; dummy - ever diagnosed with depression or anxiety } \\
\text { by doctor } \\
\text { Paternal health: BMI; dummy - longstanding illness; dummy - limiting } \\
\text { longstanding illness; dummy - ever diagnosed with depression or anxiety } \\
\text { by doctor ; dummy if partner is missing }\end{array}$ \\
\hline Housing & dummy - council housing; dummy - house suffers from dampness \\
\hline Foetal origins & $\begin{array}{l}\text { Birthweight (kg's); number of problems that occurred during child birth; } \\
\text { dummy if child was breastfed }\end{array}$ \\
\hline Nutrition & $\begin{array}{l}\text { amount of fruit consumed daily by the child (ranging from } 0 \text { to three or } \\
\text { more portions); dummy - parents pay for meal at school; amount of savoury } \\
\text { food child snacks on during the day; amount of sweet food child snacks on } \\
\text { during the day }\end{array}$ \\
\hline Parental smoking & Number of cigarettes smoked daily by mother/father \\
\hline Behavioural problems & $\begin{array}{l}\text { dummy if child has no regular bedtime; dummy if child is being bullied at } \\
\text { school; dummy if child bullies other children at school }\end{array}$ \\
\hline Lagged child health & $\begin{array}{l}\text { dummy - child had a chronic health condition at the last interview; dummy } \\
\text { if missing }\end{array}$ \\
\hline Objective child health & dummy - child currently has a chronic health condition \\
\hline Mother's health & self-rated health of the mother \\
\hline
\end{tabular}


Table A.2: Summary statistics.

\begin{tabular}{|c|c|c|c|c|}
\hline & \multicolumn{2}{|c|}{ Age $4-6$} & \multicolumn{2}{|c|}{ Age 6-8 } \\
\hline & Mean & S.E. & Mean & S.E. \\
\hline Annual income & 29159.49 & 19018.82 & 31565.82 & 21005.69 \\
\hline Ln of real permanent annual income & 10.06 & 0.64 & 10.09 & 0.63 \\
\hline Mother - does paid work & 61.68 & 0.49 & 68.35 & 0.47 \\
\hline Partner- does paid work & 76.09 & 0.43 & 75.29 & 0.43 \\
\hline Partner work missing & 0.02 & 0.01 & 18.98 & 0.39 \\
\hline Dummy - Child firstborn & 43.14 & 0.5 & 42.64 & 0.49 \\
\hline Dummy - natural father not resident in household & 22 & 0.41 & 24.6 & 0.43 \\
\hline Log of household size & 1.09 & 0.38 & 1.12 & 0.38 \\
\hline Sees Grandparents - less than once a month & 14.01 & 0.35 & 17.3 & 0.38 \\
\hline Sees Grandparents - once or twice a month & 15.97 & 0.37 & 16.61 & 0.37 \\
\hline Sees Grandparents - once or twice a week & 30.89 & 0.46 & 31.37 & 0.46 \\
\hline Sees Grandparents - several times a week & 21.11 & 0.41 & 18.09 & 0.38 \\
\hline Grandparent resident in $\mathrm{HH}$ & 3.07 & 0.17 & 2.93 & 0.17 \\
\hline Cohort members age at interview & 5.21 & 0.24 & 7.23 & 0.25 \\
\hline Child sex & 51.18 & 0.5 & 50.63 & 0.5 \\
\hline Child height $(\mathrm{cm})$ & 110.78 & 4.98 & 123.85 & 5.63 \\
\hline Dummy - child non-white & 8.2 & 0.27 & 8.6 & 0.28 \\
\hline Dummy - child was breastfed & 73.29 & 0.44 & 73.64 & 0.44 \\
\hline Mother's age & 34.44 & 5.79 & 36.67 & 5.74 \\
\hline Mother's height & 164.21 & 6.9 & 164.2 & 6.87 \\
\hline Birthweight & 3.37 & 0.6 & 3.38 & 0.58 \\
\hline Number of problems during childbirth & 0.34 & 0.67 & 0.33 & 0.66 \\
\hline Dummy - Urban & 79.04 & 0.41 & 78.19 & 0.41 \\
\hline Mother - degree & 21.01 & 0.41 & 21.46 & 0.41 \\
\hline Mother - A-level and diploma & 23.12 & 0.42 & 23.39 & 0.42 \\
\hline Mother - O level & 34.87 & 0.48 & 34.96 & 0.48 \\
\hline Partner - any degree & 18.32 & 0.39 & 18.49 & 0.39 \\
\hline Partner - A-level and diploma & 14.49 & 0.35 & 14.35 & 0.35 \\
\hline Partner - O level & 23.1 & 0.42 & 22.45 & 0.42 \\
\hline Partner's education missing & 17.56 & 0.38 & 19.53 & 0.4 \\
\hline Mothers BMI & 21.74 & 9.95 & 22.28 & 9.83 \\
\hline
\end{tabular}


...table A.2 continued

\begin{tabular}{lllll}
\hline & \multicolumn{2}{c}{ Age 4-6 } & \multicolumn{2}{c}{ Age 6-8 } \\
& Mean & S.E. & Mean & S.E. \\
\hline Dummy - mother has longstanding illness & 24.32 & 0.43 & 24.83 & 0.43 \\
Dummy - mother has limiting illness & 13.24 & 0.34 & 13.85 & 0.35 \\
Dummy - mother ever diagnosed with depression & 39.02 & 0.49 & 38.53 & 0.49 \\
Dummy - mother depression missing & 0.04 & 0.02 & 4.19 & 0.2 \\
Dummy - partner has longstanding illness & 17.65 & 0.38 & 17.9 & 0.38 \\
Dummy - partner has limiting illness & 25.76 & 0.44 & 28.29 & 0.45 \\
Dummy - partner ever diagnosed with depression & 10.56 & 0.31 & 9.32 & 0.29 \\
Dummy - partner depression missing & 17.56 & 0.38 & 19.53 & 0.4 \\
Dummy - lives in council housing & 12.48 & 0.33 & 11.33 & 0.32 \\
Dummy - places suffers from dampness & 6.59 & 0.25 & 7.48 & 0.26 \\
Servings of fruit per day & 2.34 & 0.85 & 2.31 & 0.89 \\
Dummy - child snacks on savoury foods & 47.22 & 0.22 & 47.67 & 0.23 \\
Dummy - child snacks on sweet foods & 9.2 & 0.15 & 10.2 & 0.17 \\
Dummy - parents pay for school meal & 31.92 & 0.47 & 40.24 & 0.49 \\
Dummy - mother smokes & 26.25 & 0.44 & 24.84 & 0.43 \\
Dummy - anyone smokes in room with child & 13.09 & 0.34 & 11.7 & 0.32 \\
Dummy - child has no regular bedtime & 8.44 & 0.28 & 8.1 & 0.27 \\
Dummy - child bullies or fights with other children & 7.84 & 0.27 & 7.25 & 0.26 \\
Dummy - child has been bullied or fought by other & 15.92 & 0.37 & 23.04 & 0.42 \\
children & & & & \\
Dummy - child had longstanding illness at last wave & 14.7 & 0.35 & 18.62 & 0.39 \\
Dummy - lagged child health missing & 7.57 & 0.26 & 3.68 & 0.19 \\
Mother's general health (1=excellent, 5=poor) & 2.36 & 1.01 & 2.31 & 1 \\
Dummy - child has longstanding illness & 19.4 & 0.4 & 18.64 & 0.39 \\
Dummy - child has limiting longstanding illness & 5.41 & 0.23 & 6.22 & 0.24 \\
General health of child (1=poor, 5=excellent) & 4.33 & 0.85 & 4.49 & 0.77 \\
\hline N & 11590 &. & 10552 &. \\
\hline & & & &
\end{tabular}


Table A.3: Instrument validity - joint significance of instruments

\begin{tabular}{llll}
\hline \hline & Pooled & MCS3 & MCS4 \\
\hline IV1 & 0.767 & 0.846 & 0.509 \\
IV2 & 0.768 & 0.821 & 0.530 \\
IV3 & 0.481 & 0.709 & 0.270 \\
IV4 & 0.464 & 0.371 & 0.425 \\
IV5 & 0.038 & 0.082 & 0.040 \\
\hline
\end{tabular}

Notes: This table reports p-values on the joint significance of instruments from a regression of a child's birthweight on the base case variables and the instruments.

Instruments used: IV1: local unemployment rate. IV2: lagged local unemployment rate ( $t-1) . I V 3:$ unemployment rate and business growth rate. IV4: unemployment rate, business growth rate, and regional GDI (gross domestic income per head). IV5: occupational status of the child's grandparents.

Table A.4: Proportions of children with each chronic condition in the MCS

\begin{tabular}{lcccc}
\hline & \multicolumn{2}{c}{ MCS3 } & \multicolumn{2}{c}{ MCS4 } \\
& $\mathrm{N}$ & $\%$ & $\mathrm{~N}$ & $\%$ \\
\hline Endocrine nutritional and metabolic disease & 12361 & 0.37 & 11417 & 0.39 \\
Mental and behavioral disorders & 12361 & 0.80 & 11417 & 1.24 \\
Diseases of the nervous system & 12361 & 0.50 & 11417 & 0.65 \\
Diseases of the eye and adnexa & 12361 & 1.08 & 11417 & 0.85 \\
Diseases of the ear and mastoid process & 12361 & 1.86 & 11417 & 1.65 \\
Diseases of the blood and circulatory system & 12361 & 0.44 & 11417 & 0.39 \\
Diseases of the respiratory system & 12361 & 8.03 & 11417 & 7.32 \\
Diseases of the digestive system & 12361 & 0.95 & 11417 & 0.88 \\
Diseases of skin and subcutaneous tissue & 12361 & 4.01 & 11417 & 3.36 \\
Diseases of the musculoskeletal system and connective tissue & 12361 & 0.56 & 11417 & 0.68 \\
Diseases of the genitourinary system & 12361 & 0.55 & 11417 & 0.50 \\
Congenital malformations and deformations & 12361 & 0.88 & 11417 & 0.82 \\
Injury poisoning and consequences of external causes & 12361 & 1.04 & 11417 & 0.93 \\
Findings not elsewhere classified & 12361 & 1.93 & 11417 & 1.76 \\
\hline Any long-standing chronic condition & 12361 & 19.34 & 11417 & 18.44 \\
Any limiting long-standing chronic condition & 12361 & 5.74 & 11417 & 6.18 \\
\hline
\end{tabular}


Table A.5: Summary of first stage statistics. For permanent income.

\begin{tabular}{|c|c|c|c|}
\hline & Pooled sample & Age 4-6 & Age 6-8 \\
\hline \multicolumn{4}{|l|}{ No controls } \\
\hline Underidentification statistic & 975.936 & 766.568 & 873.986 \\
\hline Underidentification p-value & 0.000 & 0.000 & 0.000 \\
\hline First-stage F & 1216.028 & 951.884 & 1101.972 \\
\hline \multicolumn{4}{|l|}{ Base case } \\
\hline Underidentification statistic & 152.740 & 136.406 & 109.931 \\
\hline Underidentification p-value & 0.000 & 0.000 & 0.000 \\
\hline First-stage F & 158.603 & 141.980 & 112.930 \\
\hline \multicolumn{4}{|l|}{ Base case + Parental health } \\
\hline Underidentification statistic & 154.073 & 137.437 & 112.151 \\
\hline Underidentification p-value & 0.000 & 0.000 & 0.000 \\
\hline First-stage F & 160.359 & 142.869 & 115.604 \\
\hline \multicolumn{4}{|l|}{ Base case + Housing } \\
\hline Underidentification statistic & 144.715 & 130.262 & 103.287 \\
\hline Underidentification p-value & 0.000 & 0.000 & 0.000 \\
\hline First-stage F & 149.929 & 135.226 & 105.947 \\
\hline \multicolumn{4}{|l|}{ Base case + Foetal origins } \\
\hline Underidentification statistic & 149.194 & 134.687 & 105.573 \\
\hline Underidentification p-value & 0.000 & 0.000 & 0.000 \\
\hline First-stage F & 154.829 & 140.153 & 108.292 \\
\hline \multicolumn{4}{|l|}{ Base case + Nutrition } \\
\hline Underidentification statistic & 152.326 & 134.946 & 110.429 \\
\hline Underidentification p-value & 0.000 & 0.000 & 0.000 \\
\hline First-stage F & 158.118 & 140.156 & 113.483 \\
\hline \multicolumn{4}{|l|}{ Base case + Parental smoking } \\
\hline Underidentification statistic & 154.619 & 137.246 & 112.580 \\
\hline Underidentification $\mathrm{p}$-value & 0.000 & 0.000 & 0.000 \\
\hline First-stage F & 160.811 & 142.896 & 115.916 \\
\hline \multicolumn{4}{|c|}{ Base case + Behavioural problems } \\
\hline Underidentification statistic & 152.376 & 135.426 & 110.549 \\
\hline Underidentification p-value & 0.000 & 0.000 & 0.000 \\
\hline First-stage F & 158.291 & 140.968 & 113.677 \\
\hline \multicolumn{4}{|l|}{ Base case + all } \\
\hline Underidentification statistic & 145.377 & 130.123 & 105.379 \\
\hline Underidentification p-value & 0.000 & 0.000 & 0.000 \\
\hline First-stage F & 150.885 & 134.593 & 108.441 \\
\hline
\end{tabular}

Notes: IV used: local unemployment rate. Variables included in each specification are listed in Table A.1. Underidentification test=Kleibergen-Paap test; First-stage F refers to F test of excluded instruments in the first stage. 
Table A.6: The effect of income on child health with controls for transmission channels. Excluding children with limiting chronic conditions.

\begin{tabular}{|c|c|c|c|c|c|c|}
\hline \multirow[b]{2}{*}{ Controls } & \multicolumn{2}{|c|}{ Pooled sample } & \multicolumn{2}{|c|}{ Age 4-6 } & \multicolumn{2}{|c|}{ Age 6-8 } \\
\hline & $\begin{array}{l}\text { OLS } \\
(1)\end{array}$ & $\begin{array}{l}\text { IV } \\
(2)\end{array}$ & $\begin{array}{l}\text { OLS } \\
(3)\end{array}$ & $\begin{array}{l}\text { IV } \\
(4)\end{array}$ & $\begin{array}{l}\text { OLS } \\
(5)\end{array}$ & $\begin{array}{l}\text { IV } \\
(6)\end{array}$ \\
\hline No controls & $\begin{array}{l}0.203 * * * \\
(0.009)\end{array}$ & $\begin{array}{l}0.456 * * * \\
(0.033)\end{array}$ & $\begin{array}{l}0.210 * * * \\
(0.012)\end{array}$ & $\begin{array}{l}0.391 * * * \\
(0.044)\end{array}$ & $\begin{array}{l}0.190 * * * \\
(0.011)\end{array}$ & $\begin{array}{l}0.387 * * * \\
(0.038)\end{array}$ \\
\hline Base case & $\begin{array}{l}0.129 * * * \\
(0.014)\end{array}$ & $\begin{array}{l}0.296 * * \\
(0.134)\end{array}$ & $\begin{array}{l}0.134 * * * \\
(0.019)\end{array}$ & $\begin{array}{l}0.248 \\
(0.166)\end{array}$ & $\begin{array}{l}0.122 * * * \\
(0.017)\end{array}$ & $\begin{array}{l}0.371 * * \\
(0.171)\end{array}$ \\
\hline $\begin{array}{l}\text { Diagnostic tests for base cas } \\
\text { First-stage F } \\
\text { Underidentification statistic } \\
\text { Underidentification p-value }\end{array}$ & pecification & $\begin{array}{l}147.213 \\
142.051 \\
0.000\end{array}$ & & $\begin{array}{l}131.695 \\
126.681 \\
0.000\end{array}$ & & $\begin{array}{l}100.532 \\
98.018 \\
0.000\end{array}$ \\
\hline $\begin{array}{l}\text { Base case plus controls for } \\
\text { Parental health }\end{array}$ & $\begin{array}{l}0.114 * * * \\
(0.014)\end{array}$ & $\begin{array}{l}0.306^{* *} \\
(0.134)\end{array}$ & $\begin{array}{l}0.120 * * * \\
(0.019)\end{array}$ & $\begin{array}{l}0.264 \\
(0.165)\end{array}$ & $\begin{array}{l}0.107 * * * \\
(0.017)\end{array}$ & $\begin{array}{l}0.375^{* *} \\
(0.171)\end{array}$ \\
\hline Housing & $\begin{array}{l}0.120 * * * \\
(0.014)\end{array}$ & $\begin{array}{l}0.291 * * \\
(0.140)\end{array}$ & $\begin{array}{l}0.125^{* * * *} \\
(0.019)\end{array}$ & $\begin{array}{l}0.239 \\
(0.173)\end{array}$ & $\begin{array}{l}0.113 * * * \\
(0.017)\end{array}$ & $\begin{array}{l}0.374 * * \\
(0.180)\end{array}$ \\
\hline Foetal origins & $\begin{array}{l}0.128 * * * \\
(0.014)\end{array}$ & $\begin{array}{l}0.311 * * \\
(0.135)\end{array}$ & $\begin{array}{l}0.133 * * * \\
(0.019)\end{array}$ & $\begin{array}{l}0.262 \\
(0.166)\end{array}$ & $\begin{array}{l}0.122 * * * \\
(0.017)\end{array}$ & $\begin{array}{l}0.390 * * \\
(0.175)\end{array}$ \\
\hline Nutrition & $\begin{array}{l}0.121 * * * \\
(0.014)\end{array}$ & $\begin{array}{l}0.268 * * \\
(0.135)\end{array}$ & $\begin{array}{l}0.124 * * * \\
(0.019)\end{array}$ & $\begin{array}{l}0.211 \\
(0.167)\end{array}$ & $\begin{array}{l}0.118 * * * \\
(0.017)\end{array}$ & $\begin{array}{l}0.359 * * \\
(0.171)\end{array}$ \\
\hline Parental smoking & $\begin{array}{l}0.123 * * * \\
(0.014)\end{array}$ & $\begin{array}{l}0.298 * * \\
(0.133)\end{array}$ & $\begin{array}{l}0.128 * * * \\
(0.019)\end{array}$ & $\begin{array}{l}0.242 \\
(0.165)\end{array}$ & $\begin{array}{l}0.118 * * * \\
(0.017)\end{array}$ & $\begin{array}{l}0.375^{* *} \\
(0.169)\end{array}$ \\
\hline Behavioural problems & $\begin{array}{l}0.115^{* * * *} \\
(0.014)\end{array}$ & $\begin{array}{l}0.284 * * \\
(0.134)\end{array}$ & $\begin{array}{l}0.119 * * * \\
(0.019)\end{array}$ & $\begin{array}{l}0.230 \\
(0.166)\end{array}$ & $\begin{array}{l}0.110 * * * \\
(0.017)\end{array}$ & $\begin{array}{l}0.367 * * \\
(0.171)\end{array}$ \\
\hline All jointly & $\begin{array}{l}0.090 * * * \\
(0.014)\end{array}$ & $\begin{array}{l}0.287 * * \\
(0.140)\end{array}$ & $\begin{array}{l}0.091 * * * \\
(0.019)\end{array}$ & $\begin{array}{l}0.221 \\
(0.172)\end{array}$ & $\begin{array}{l}0.086^{* * * *} \\
(0.017)\end{array}$ & $\begin{array}{l}0.378^{* *} \\
(0.180)\end{array}$ \\
\hline $\mathrm{N}$ & 20802 & 20802 & 10913 & 10913 & 9889 & 9889 \\
\hline
\end{tabular}

Notes: Each coefficient represents a separate regression. Variables included in each specification are listed in Table A.1. IV uses local unemployment rate as instrumental variable. Underidentification test=Kleibergen-Paap test; First-stage F refers to F test of excluded instruments in the first stage. Cluster-robust standard errors in parentheses. $* * * p<0.01, * * p<0.05, * p<0.1$. 
Figure A.1: Counties and Unitary Authorities in the UK

United Kingdom: Local Authority Districts, Counties and Unitary Authorities, ${ }^{1} 2011$

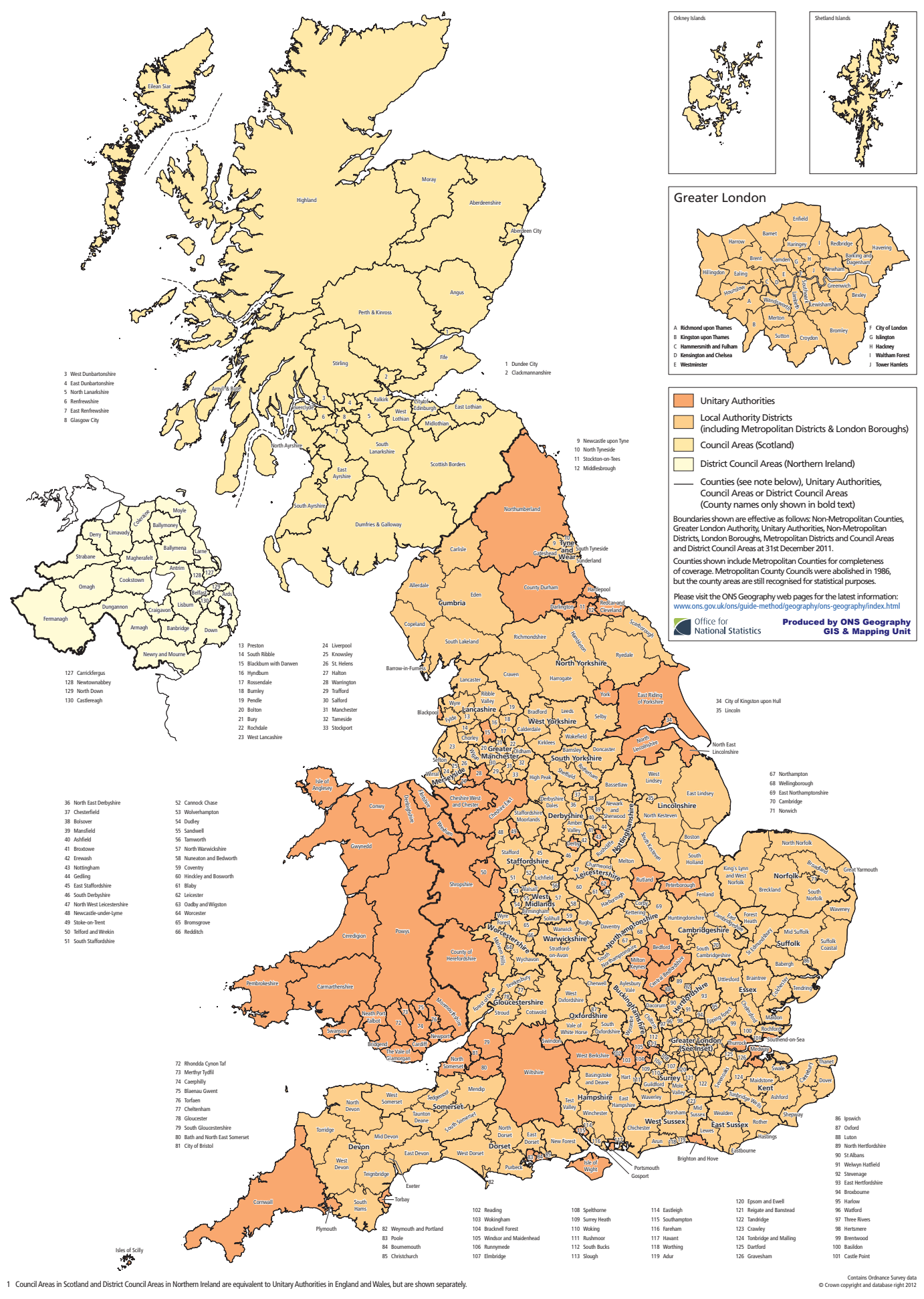

